\title{
An Analysis of Generic Features of Acknowledgments in Academic Writing: Native Speakers of English vs. Non-Native (Iranian)
}

\author{
Davud Kuhi ${ }^{1} \&$ Shirin Rezaei ${ }^{1}$ \\ ${ }^{1}$ English Language Department, Maragheh Branch, Islamic Azad Universitty, Maragheh, East Azarbaijan, Iran \\ Correspondence: Shirin Rezaei, English Language Department, Maragheh Branch, Islamic Azad Universitty, \\ Maragheh, East Azarbaijan, Iran. E-mail: shirinrezaee89@gmail.com
}

Received: October 22, 2013 Accepted: December 15, 2013 Online Published: January 23, 2014

doi:10.5539/ijel.v4n1p19

URL: http://dx.doi.org/10.5539/ijel.v4n1p19

\begin{abstract}
The literature on the generic structure of acknowledgment has revealed that, beyond the role it plays in academic gift giving and self-presentation, the textualization of gratitude reveals the effect of disciplinary, sociocultural and contextual variations on shaping this genre (Hyland, 2003; Giannoni, 2002; Yang, 2012). However, there is relatively scant research on the ways that acknowledgements in different genres are characterized by their distinctive communicative purposes. To fill this gap, this study analyzes through two phases the acknowledgment sections of various genres (20 MA \& $20 \mathrm{PhD}$ theses, 20 textbooks, and 20 research articles) written by native speakers of English $(n=40)$ and Iranian $(n=40)$ in applied linguistics. The results of move analysis phase which insights was from Swales' (1990) model, showed that genre of acknowledgment was constituted of a main "Thanking" move framed by two optional "Reflecting" and "Announcing" moves in theses, two optional "Framing" and "Announcing" moves in textbooks, and one optional "Framing" move in research articles. Despite observing the "Thanking move" in acknowledgment sections of all genres, cross-generic differences were also found in the type and frequency of constituent steps used to realize this move and other optional moves. These differences indicate how the contextual, cultural, and institutional forces influence the production and reception of academic genres.
\end{abstract}

Keywords: academic writing, genre, move, systemic functional linguistics

\section{Introduction}

Acknowledgments are universal features of academic writing which are commonly used in Theses and books and have increasing presence in research articles (Giannoni, 2002). This genre not only provides a space for writers to signify interpersonal relationship, but reflects their personal identity, socio cultural and contextual or conventional values (Hyland, 2004; Cheng, 2012). In other words, acknowledgments are not entirely personal but can also be context-embedded. For example, how writers position themselves as student, researcher, or book author could affect their expressions of gratitude. That is, distinctive communicative purposes of different genres can influence the shaping of generic structures of acknowledgments.

Previous studies have mainly focused on the expressions of gratitude and their generic structures used by a single ethnic group in one social context across disciplines (Hyland, 2004; Hyland \& Tse, 2004; Giannoni, 2006) or the comparisons of acknowledgments written by native speakers of English (NSE) and non-native speakers of English in two different social contexts (Giannoni, 2002; Lasaky, 2011; Al-Ali, 2010; Cheng, 2012). However, there is relatively scant research on comparing acknowledgments of various academic genres (i.e., Textbooks, Research articles, MA \& PhD Theses) written by NSE and NNSE. Furthermore, none of the existing research on acknowledgments has applied systemic functional linguistic text analysis to show how "discourse context influences" of each genre determine the author's linguistic and functional choices in two different cultures. Therefore, this study aims to compare and contrast acknowledgments of various genres written by NSE and NNSE (Iranian) to provide a contextual framework of the factors that are thought to be responsible for the possible crossgeneric variations.

The importance of genre knowledge in helping language learners to understand and master academic, professional or educational discourse has been widely acknowledged for over two decades (Swales, 2004). Bhatia defines a genre as a recognizable communicative event characterized by a set of communicative purpose(s) identified and mutually understood by the members of the professional or academic community in 
which it regularly occurs. He claims that "by analyzing genre, analysts can understand how a particular genre defines, organizes and finally communicates social reality" (Bhatia, 1993, p. 18). Therefore, genre approaches by developing a socially informed theory of language and an authoritative pedagogy grounded in research of texts and contexts have had an important impact on the ways we see language use and on literacy education around the world (Hyland, 2002).

Hyon (1996) identifies three main traditions in contemporary genre studies, which can be seen as complementary, rather than competing approaches: New Rhetoric (e.g., Berkenkotter \& Huckin, 1995); Australian educational linguistics (e.g., Martin, 1989; Halliday \& Martin, 1993); and English for Specific Purposes (ESP) (e.g., Swales, 1990; Bhatia, 1993). However, ESP and Australian educational linguistics are more pedagogy oriented while New Rhetoric is more theoretically and research oriented (Coffin, 2001). Hence, ESP scholars have tried to describe texts of different disciplines through analyzing the Moves. Swales defines Move in genre analysis as "a discoursal or rhetorical unit that performs a coherent communicative function in a written or spoken discourse" (Swales, 2004, p. 29). To relate Moves to their Sub-moves (steps), Nwogu (1997) argues that Moves are conventional schema, consisting of hierarchically ordered knowledge structures and Sub-moves are their constituent elements.

Systemic functional genre studies often known as "the Sydney School" of genre studies are based on the work of systemic functional linguists such as Halliday (1994); Halliday and Matthiessen (2004), Halliday and Hasan (1985). Halliday's SFL studies the functional and situational organization of language in the social context (Halliday, 1985, p. 11). According to this model, functional bases of grammatical phenomena are divided into three broad areas, called metafuctions: the ideational, the interpersonal, and the textual. I. The ideational metafunction concerns the representation of the speaker's individual experience, II. The interpersonal metafunction concerns the expression of the speaker's attitudes, III. The textual metafunction concerns the text forming resources of language (Halliday, 1987, pp. 112-113; Morley, 1985, p. 48). In the conversion of semantic metafunctions into structural patterns, three lexicogrammatical systems of Transitivity, Mood and Theme are at work: I. Transitivity involves a ternary configuration of a process, participants and circumstances, II. Mood realizes the speech functions, III. Theme concerns how "information within individual clauses" is embedded in "the larger text" (Martin, Matthiessen, \& Painter, 1997, p. 21).

Among academic genres that have been favored by researchers for move analysis the genre of acknowledgment has been relatively neglected (Hyland, 2003) and, as a result, little is known of their structure and expression. Giannoni (2002) was the first genre analyst who studied the difference between English and Italian research article acknowledgements and identified two moves, an optional "introductory move" and an obligatory "credit mapping" move comprising three possible steps; allocating credit to institutions, to individuals, and claiming responsibility. His research concluded that generic structures of acknowledgements in journal articles not only reflect the differences of the various disciplines, but are also affected by the patterns of national disciplinary communities. Following Giannoni (2002), Hyland (2004) explored thanks expressing in the genre of acknowledgements in PhD and MA dissertations written by 240 Hong Kong English speakers from 6 different broad academic disciplines; Electronic engineering, computer science, business studies, biology, applied linguistics, and public administration. He identified three moves in those acknowledgements: a reflecting move, a thanking move and an announcing move. The results of that study demonstrated that acknowledgments not only "play an important role in promoting a competent, even rhetorically skilled, scholarly identity" of the acknowledgers, but also reveal the social and cultural characteristics of acknowledgments in situated settings (Hyland, 2003, p. 266). Giannoni (2006) looked into the genre of acknowledgements in English academic books. Cross-disciplinary differences in the distribution of pragmalinguistic features, such as hyperbole, irony, and emotivity, were found in the hard sciences (mathematics, medicine and biology) and the soft sciences (applied linguistics, economics, and social sciences). Adding to Hyland' (2004) three-move framework, Al-Ali (2010) proposed an eight-move structure to incorporate the socio-cultural components (e.g., religious beliefs, academic and social conventions) of the Arabic acknowledgement practice. He maintains that the choice of language in acknowledgments very much depend on some socio-cultural and religious motivations. For instance, some specific features in Arabic acknowledgements are praising and thanking Allah (God) and invoking and blessing from God's (Allah's) favors upon the thanked addressees. The most recent research on DA has been by Lasaky (2011). He relied on Hyland's (2004) framework to compare acknowledgments in PhD Theses written by native English speakers (NSE) and non-native speakers (Iranian) students (NNSE) majoring in applied linguistics. Similar to Al-Ali (2010), Lasaky also identified the step of Thanking Allah (God) in the NNSE group.

Majority of studies discussed above confirmed that disciplinary conventions and socio-cultural factors affect how an acknowledgment is structured. However, there is relatively scant research on comparing acknowledgments of 
various academic genres (i.e., Textbooks, Research articles, MA \& PhD Theses) written by NSE and NNSE. In order to fill this gap, the present study, based on two approaches of genre analysis in applied linguistics ESP (English for Specific Purposes) and SFL (Systemic Functional Linguistics), aims to compare and contrast acknowledgments of various genres written by NSE and NNSE (Iranian) to provide a contextual framework of the factors that are thought to be responsible for the possible cross-generic and cross-cultural variations. In order to do so following research questions are addressed in this study:

1) What moves constitute the generic structures of acknowledgments written by NSE and NNSE (Iranian) authors in various academic genres?

2) How the distribution of minor functions in acknowledgment sections of various genres are a direct reflection of the communicative purposes of each genre?

\section{Method}

\subsection{Corpus and Procedure}

The present study focused on 80 written texts consisting of four sub-corpora written by Native speakers of English $(n=40)$ and Iranian $(n=40)$ authors, respectively. Each of the sub-corpora is composed of 20 research articles, 20 MA theses, $20 \mathrm{PhD}$ theses, and 20 textbooks.

These academic texts were chosen as follow:

A. Iranian Theses' acknowledgement texts were chosen randomly out of MA and PhD ones submitted to two universities in Tabriz. The NSE' acknowledgment texts were selected randomly from Proquest.com site out of many texts from different English speaking country universities. These theses were limited to those presented from 2007 to 2012. The universities in which the theses were collected are detailed in Appendices $1 \& 2$.

B. Articles' acknowledgment texts were randomly collected from 20 articles, published in the most prestigious Anglo-American and Iranian journals between 2000 and 2012, as detailed in Appendix 4.

C. Textbooks' acknowledgments were chosen randomly from 20 textbooks written by native English and Iranian authors. The textbooks in which acknowledgments were provided are detailed in Appendix 3.

\subsection{Criteria for the Selection of the Texts}

The disciplinary focus of the corpus was limited to applied linguistics as defined by Wilkins (1999). The selection of texts from a single discipline was intended to avoid any overgeneralizations of the results due to possible discipline-specific characteristics. The criterion which was applied for ensuring that the theses were written by NSE was checking authors' name. In selection of textbooks, the major criterion was to include those which are widely used in the syllabuses of applied linguistic courses in our context. Finally, the criterion for selecting journals was the accessibility to the most important publications. Moreover, to make sure about writers' nationality (Native speaker of English) their names and affiliation were checked.

\subsection{Models of Analysis}

Based on two approaches of genre analysis in applied linguistics ESP (English for Specific Purposes) and SFL (Systemic Functional Linguistics), this study aims to compare and contrast acknowledgments of various genres written by NSE and NNSE (Iranian) to provide a contextual framework of the factors that are thought to be responsible for the possible cross-generic and cross-cultural variation in two phases. In the move analysis phase which insights was from Swales' (1990) model, the Moves-Sub moves used in the acknowledgments were compared. In the second phase, following SFL tradition, based on the work of Halliday and Matthiesen (2004), three types of metafunctions (Ideational, Interpersonal and Textual) used in Sub-moves were analyzed and then compared in order to provide insights into the meaning and effectiveness of acknowledgment texts.

\subsection{Data Analysis Procedures}

In genre analysis phase, to identify the Moves/Sub-moves, propositions were considered to be the unit of analysis since each proposition can generally have an independent communicative purpose although sometimes a Move or a Sub-move can be as long as one or more paragraphs. Some Moves/Sub-moves had been used more than once in some of acknowledgment sections based on the demands from the subject matters of those texts. However, despite the frequent use of some Moves/Sub-moves in most texts, as the frequency of using/not using a Move/Sub-move was the matter of concentration, only a single use of a particular Move or Sub-move was considered sufficient for any acknowledgment to be included in the frequencies. To ensure that there was a consensus of categorization of moves and steps, this examination was performed by the researcher and one NNS colleague. During the multifunctional analysis phase, a clause which is a product of three kinds of co-existing 
structures was considered as a unit of analysis. Thus, initially each text was divided into its constituents; that is, its clauses were identified. Then clause constituents were determined in each clause of the acknowledgment texts and a functional label was ascribed to the nodes defined in the clause structure: e.g., the prepositional phrase "in this study" is named as "Adjunct" in the functional labeling process. After clause constituents were given three sets of functional labels, they were classified in terms of the linguistic phenomena they represent in the polyphonic structure of the texts, e.g., the adjunct "in this study" is an indicator of the linguistic phenomena "circumstances adjunct" and is grouped with the other adjunct operators under the relevant category. Finally, the total number of the functional constituents in each category was entered into an Excel spreadsheet. After the frequencies and percentages were calculated for each category by using Excel, tables of frequency were formed out of the input from the sum total of the functional units in each category.

\section{Results and Discussion}

\subsection{First Phase: Results and Discussion f Move Analysis}

The generic structure of acknowledgements revealed the following component moves. The order of their appearance is not a canonical order, it is one that was common in the corpus text. Each individual move and related steps will be described by examples from the corpus.

\subsubsection{MA and PhD Thesis Acknowledgments}

The result of genre analysis of MA \& PhD acknowledgements is similar to the one that described in the previous study by Hyland (2004) except "Thanking God" step. MA \& PhD acknowledgment is constituted of a main "Thanking" move framed by two optional "Reflecting" and "Announcing" moves.

Table 1. Percentage of move components for MA \& PhD thesis acknowledgements

\begin{tabular}{ccccc}
\hline Component Moves of acknowledgements & Iranian MA & $\begin{array}{c}\text { NSE } \\
\text { MA }\end{array}$ & $\begin{array}{c}\text { Iranian } \\
\mathrm{PhD}\end{array}$ & $\begin{array}{c}\text { NSE } \\
\text { PhD }\end{array}$ \\
\hline $\begin{array}{c}\text { Reflecting Move } \\
\text { Thanking Move } \\
\text { Thanking God }\end{array}$ & 0 & 10 & 10 & 20 \\
Presenting participants & 30 & 0 & 20 & 0 \\
Thanking supervisor(s) and other academics & 100 & 100 & 100 & 100 \\
Thanking for data access and clerical ,technical & 30 & 30 & 80 & 90 \\
support and financial support & & & & \\
Thanking for moral support & 70 & 60 & 90 & 90 \\
Announcing move & & & & \\
Accepting responsibility & 0 & 10 & 10 & 0 \\
Dedicating the thesis & 10 & 10 & 0 & 10 \\
\hline
\end{tabular}

\section{Reflecting move}

Hyland (2004) proposes that in Reflective move the authors comment on their experiences while writing their $\mathrm{MA}$ and $\mathrm{PhD}$ dissertations. As its frequency in corpus data shows, it is very peripheral to the genre's main communicative purpose. The following examples shows the kind of realization available in corpus texts:

1). This project developed in bursts, starting and stopping, then re-starting in a new direction, over many years. (NSEPT5)

2). This thesis was a self-exploratory journey of love and learning which took almost three years in making; the time in which my own identity has been undergoing immense transformation. (IPT3)

\section{Thanking move}

This move is the main body of acknowledgments, as confirmed by its presence throughout the thesis acknowledgments. It is realized by six component steps containing the thanks offered to person or groups of people (e.g., supervisors, academics, institutions, friends, and family, etc.). 


\section{Thanking God}

As Al-Ali (2005) proposes that this step which is only employed by Iranian students reflects Muslims' attitudes towards their religious beliefs.

3). First and for most, I am grateful to my God who best owed on me enough time and energy to complete the present thesis. (IMT4)

\section{Presenting participants}

The main purpose of this step is to provide a means of introducing the people to be thanked in the following steps. It usually happens at initial position or after the "Thanking God" step.

4). Gratitude and thanks are due to many who made this possible. (NSEMT2)

5). There are many people without whom this study would not have been possible. (IMT5)

\section{Thanking for academic assistance}

Hyland (2003) indicates that through this step writers shows their gratefulness for any kind of intellectual help they received from members in the academic community. It is the only step that has been observed in all texts and can be regarded as an obligatory constituent and the backbone of this genre (Hyland, 2003). NSE writers of this study often tended to address academic members by his/her full name or first name, whereas Iranian thesis writers opted for Title + Full Name. This is perhaps because teachers and students are more or less on equal terms in the American context while in Iranian context teachers are usually considered authorities who demand respect from their students.

6). would like to express my thankful expressions to $d r$. x, the supervisor of study ... (IMT6)

7). I would like to thank my advisor, Bill Labov, for being an excellent teacher. (NSEPT6)

\section{Thanking for resources}

As Hyland (2003) mentions this step is meant to show that writers are thankful to those participants, experts, and institutions that helped them in providing and analysis of data and also universities or family members that provided grants for conducting the research. According to corpus data, higher proportion of thanks in NSE corpus was for funding and fellowship support while it was more frequently for administrative support in Iranian acknowledgments. This seems to imply that Iranian researchers are often driven by incentives other than those of purely academic inquisition (Shahriari, 2009).

8). Special gratitude goes to Goldis language... and its academic and administrative staff ... (IPT1)

9). Finally, I want to express my gratitude to all those who made my grant possible, and for their believing that I could do it. (NSEPT2)

\section{Thanking for moral support}

In this step, writers thank family members and close friends for their patience, care and encouragements during writing the theses. As table shows this step was employed in high frequency in corpus texts.

10). I am eternally grateful to my parents, and my husband. ... who have supported me with patience and encouragement.( IPT5)

11). First, I thank friends who kept me going throughout the years:

(NSEPT4)

\section{Announcing move}

This move occurs with a low frequency in corpus data and includes two constituent steps, accepting responsibility and dedicating the thesis.

\section{Accepting responsibility}

Through this step, writers accept responsibility of any flows or shortcomings occurred in their research. "On the interpersonal plane, this step emphasized the contrast between collaboration and responsibility" (Giannoni, 2002, p. 22).

12). For any shortcoming, to one to blame is only me. (IPT4)

13). It should be noted, of course, any short-comings or faults in this text are all my own. (NSEMT3)

\section{Dedicating the thesis}

This step is employed by the writers who wish to express their special gratitude toward a certain person as a reward for a unique effort. 


\section{4). I lovingly dedicate this dissertation to my mother. (IMT7)}

15). This thesis is dedicated to: my dad Bob, my mom Mary and my sister and brother ... (NSEMT1).

\subsubsection{Textbook Acknowledgments}

The results of the generic structure of textbook acknowledgements revealed that textbook acknowledgments were constituted of a main "Thanking" move framed by two optional "Framing" and "Announcing" moves.

Table 2. Percentage of move components for textbook acknowledgements

\begin{tabular}{ccc}
\hline Component Moves of acknowledgements & Iranian & NSEA \\
\hline $\begin{array}{c}\text { Framing Move } \\
\text { Citing parent texts or event } \\
\text { Thanking move }\end{array}$ & 20 & 20 \\
presenting participants & 50 & 20 \\
thanking for individual contributions & 90 & 40 \\
thanking for resources & 70 & 60 \\
thanking for moral support & 70 & 10 \\
Thanking for permission from copyright holders & 0 & 80 \\
Announcing move & & 50 \\
Requiring for informing any omissions of copyright holder & 0 & 0 \\
Requiring for feedback & 20 & 0 \\
Dedicating the book & 20 & \\
\hline
\end{tabular}

\section{Framing move}

This move is collateral to the genre's main communicative purpose (Giannoni, 2002). It contextualizes or frames the information that follows by outlining the book's ancestry, in terms of earlier texts or event from which it developed. Iranian corpus, unlike its English counterpart, oriented to parent text rather than event:

16). My sincere thanks are due to Dr. parvis maftoon for his invaluable assistance, advice, and meticulous comments through writing my PhD dissertation, from which this book is derived. (IB6)

17). Teaching and learning in the language classroom has developed out of the courses I have taught over twenty-five. ... (NSEB4)

\section{Thanking Move}

This move is the main purposes of this genre in book acknowledgments, as confirmed by its presence throughout the corpus. It is realized by five component steps whose appearance is similar to those of theses except Thanking for permission step.

\section{Thanking for permission from copyright holders}

This step collates acknowledgements for permission that writers get from copyright holders for the use of copyright material identified in their book. While this step was found in $90 \%$ of NSE book acknowledgments, it was not included in Iranian corpus. The high frequency of this step in NSE corpus reveals the importance of copyright act in western context.

18). The author and publisher are grateful to those who have given permission to reproduce the following extracts and. (NSEB2)

\section{Announcing Move}

This step includes three constituent steps, requiring for informing any omissions of copyright holder names, requiring for feedback, and dedicating the book.

\section{Requiring for informing any omissions of copyright holder names}

Through this step, the writer expresses that although every effort has been made to trace and contact copyright 
holders before publication, this has not been possible in some cases. So s/he will be pleased to rectify any errors or omissions at the earliest opportunity. This step occurred in only NSE book acknowledgments.

19). It has not been possible to identify, or trace, sources of all the materials used and in such cases the publishers would welcome information from copyright owner. (NSEB5)

\section{Requiring for feedback}

This step was only present in Iranian corpus. In this step, the writer announces valuing any comment and suggestions for the book's future improvement.

20). I sincerely ask for feedback and help from the readers for further improvement. (IB9)

\section{Dedicating the book}

Textbook writers like those of theses by including this step wish to express their special gratitude toward a certain person as a reward for a unique effort. This step occurred with low frequency only in Iranian corpus. It might be because that writers (NSE and Iranian) usually include this step separately mostly on the first pages of their book.

21). We would like to dedicate this book to our dear colleagues and students.

(IB2)

\subsubsection{Research Article Acknowledgments}

Genre analysis of Research article acknowledgements revealed that articles' acknowledgments of this study were constituted of a main "Thanking" move framed by one optional "Framing" move.

Table 3. Percentage of move components for article acknowledgement

\begin{tabular}{ccc}
\hline Component Moves of acknowledgements & Iranian & NSE \\
\hline Framing move & 0 & 30 \\
Citing parent texts or event & & \\
Thanking move & 40 & 40 \\
Acknowledging institutional support, and/or & 90 & 100 \\
Acknowledging individual contribution & \\
\hline
\end{tabular}

\section{Framing move}

Like framing move in book acknowledgments, it contextualizes or frames the information that follows by outlining the article's ancestry, in terms of earlier texts or event from which it developed. It occurred in only NSE corpus. Giannoni (2002) argues that, in self-promotional use of the opening step when it informs readers of other publications by the same author, commercial pressures are observed. This is in line with fairclough's (1995) claim that academic discourse is being colonized by language of marketing.

22). She and the author presented the initial findings of this study at the Conference on College Composition and Communication held in 2005, in San Francisco. (NSEA1)

\section{Thanking Move}

This move is used to allocate credit to organizations or individuals whose help was crucial to the article's completion. Acknowledgments are classified according to the type of help received and are reflected in two separate steps: Acknowledging institutional support which includes acknowledgements of administrative and financial support and acknowledging individual contribution.

There was considerable variation in the amount of gratitude communicated to institutions between two corpora; ranging from the hyperbolic ("without which this research would not have been possible") in Iranian corpus to descriptions devoid of appreciation in NSE corpus. Giannoni argues that "blank acknowledgments are associated with the recognition of support from public bodies, while private organizations are often thanked explicitly" (Giannoni, 2002, p. 20).

23). We gratefully acknowledge the project reported here was supported by a grant-in-aid of research From Ferdowsi University of Mashhad in 2011 (contract code: 17407) without which this research would not have been possible. (IA6) 
24). The research was also funded in part by the Portland State University President's Council on Diversity. (NSEA3)

Although thanking for individual contributions step was present in $90 \%$ of Iranian and $100 \%$ of NSE corpus, differences were found regarding the number of acknowledged people. In contrast to NSE writers, Iranian acknowledged few people. This is probably because that Iranian use more thanking expressions for a big favor compared to situations representing small favor. Furthermore, the low number of acknowledgees in Iranian corpus probably implies more competitive rather than collaborative environment of our academic discourse.

25). I am grateful to Richard Andrews, Ron Carter, Viv Ellis, Amanda Godley, John Hardcastle, Alexandra Jaffe, Ben Rampton, Brian Street, Melinda Whong, Andrew Wright. ... (NSEA6)

According to Move analysis phase results, despite observing the "Thanking move" in acknowledgments of all genres, some noticeable cross-generic differences were found regarding which participants were acknowledged. As it is mentioned, the presence of academics, providers, and friends is almost an unvarying tradition of theses acknowledgments, but there was another participant (peer collages) involved in textbooks. The reason for this might be that, the main motivation from textbook writers' point of view is to gain recognition and prestige among the other expert members of the discourse community .Thus, thick acknowledging of these peers are taken into account by the textbook writer. This demand for enhancing the authorial credibility and professional identity of writers can also be observed in research articles. But despite this similarity, the clear separation of contributing individuals and institutions and more importantly descriptions devoid of appreciation in gratitude communicated to institutions in articles were not observed in theses and textbooks acknowledgment texts. Giannoni argues that these" blank acknowledgments are associated with the recognition of support from public bodies, while private organizations are often thanked explicitly" (Giannoni, 2002, p. 20).

Another considerable cross-generic difference was observing the "Framing move" in article and textbook's acknowledgments. Giannoni (2002) argues that, in self-promotional use of the opening step when it informs readers of other publications by the same author, commercial pressures are observed. This is in line with fairclough's (1995) claim that academic discourse is being colonized by language of marketing.

\subsection{Second Phase: Results of Multifunctional Analysis}

\subsubsection{Ideational Metafunction}

The ideational analysis of the clause as representation deals with the exploration of the Transitivity patterns. Transitivity as a major component in experiential function of the clause deals with the transmission of ideas "representing 'processes' or 'experiences': actions, events, processes of consciousness and relations" (Halliday, 1985, p. 53).

\subsubsection{Process Choice}

Process refers to a semantic verb and anything that it expresses like event, relation, physical, mental or emotional state when sorted in the semantic system of the clause is classified into material, relational, mental, verbal, behavioral, and existential processes (Halliday, 1976, p. 159). The following figures provide the percentages of processes employed in all of the identified sub-moves of the acknowledgment texts in four corpora. 


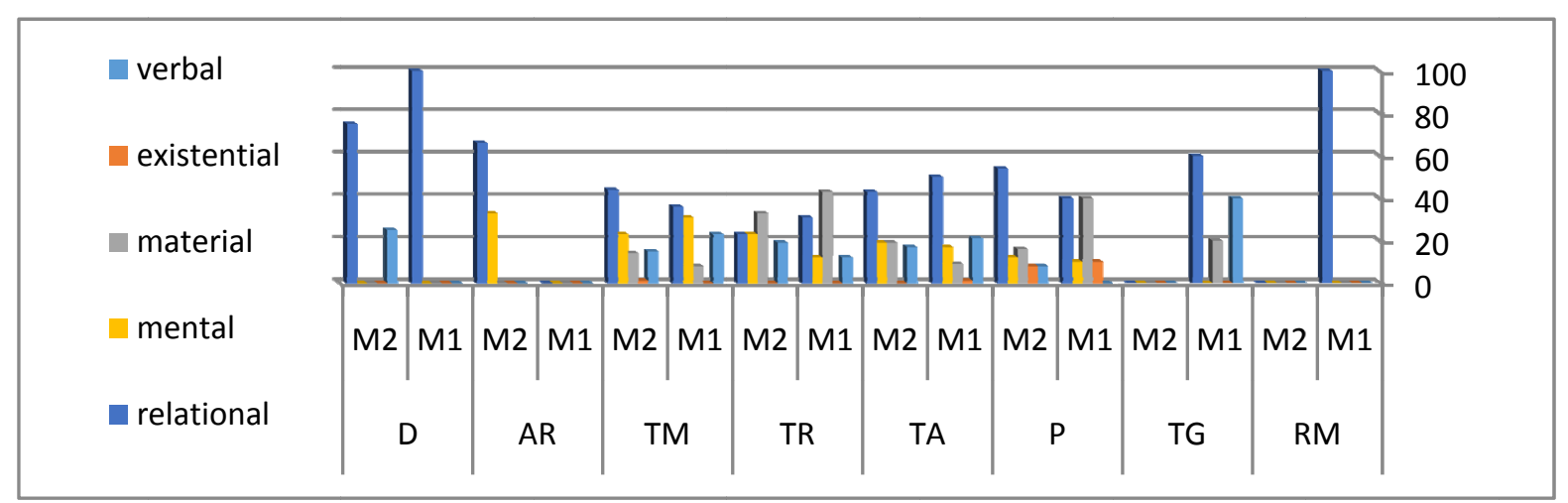

Figure 1. Distribution of process types in MA acknowledgments

(M1=Iranian MA student; M2=NSE MA student; RM=Reflective Move; TG=Thanking for God; $\mathrm{P}=$ Presenting; $\mathrm{TA}=$ Thanking for Academic assistance; $\mathrm{TR}=$ Thanking for Resources; $\mathrm{TM}=$ Thanking for Moral support; $\mathrm{AR}=$ Accepting responsibility; $\mathrm{D}=$ Dedicating the thesis)

As figure 1 indicates, relational processes are relatively high in frequency in sub-moves of the MA acknowledgment texts. The relatively high frequency of relational process is commensurate with the function of acknowledgments that are principally concerned with describing and defining the values received by writer from acknowledged people as in:

\section{6). Morley has been a constant source of encouragement. (NSEMT6)}

In contrast to relational processes focusing on classification and description, material processes are representing the doings of the participants (writer and acknowledged ones).Material processes were most intensively used in TR step as in:

27). I would like to thank Mr. X and Mrs.X, the head of the language institute who permitted me to do my research in their institute. (IMT5)

Another group of non-relational processes is represented by mental processes. These processes are concerned with the representation of the writer and acknowledged people's thoughts, feelings, and perceptions. They are highly used in TM step as in:

28). I am privileged to have such a husband who first and foremost loves God, and then unconditionally loves me. (NSEMT2)

Apart from mental and material processes, verbal processes are also used to indicate the symbolic activities of "Thanking". They are found to be relatively more frequent in TA step as in:

29). I would first like to thank my advisors. (NSEMT4)

30). Firstly, I would like to thank my thesis supervisor, Dr. X for her support, patience to this thesis. (IMT5)

The last class of processes to be discussed consists of existential processes: they are lowest in frequency. The reason why existential processes are rarely used is that it usually occurred in presenting step that is typically short and rarely more than a sentence in length, as in:

31). There are many people without whom this study would not have been possible. (IMT5) 


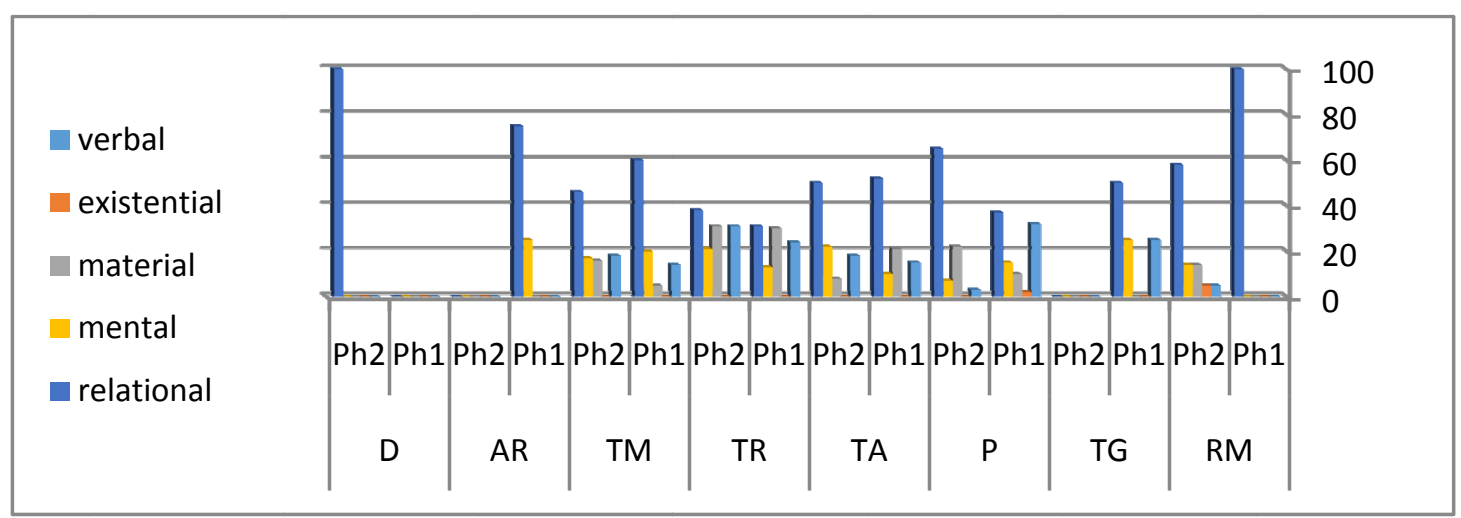

Figure 2. Distribution of process types in $\mathrm{PhD}$ acknowledgments

( $\mathrm{Ph} 1=$ Iranian $\mathrm{PhD}$ student; $\mathrm{Ph} 2=\mathrm{NSE} \mathrm{PhD}$ student; $\mathrm{P}=$ Presenting; $\mathrm{TA}=$ Thanking for Academic assistance; $\mathrm{TR}=$ Thanking for Resources; $\mathrm{TM}=$ Thanking for Moral support; $\mathrm{AR}=$ Accepting responsibility; $\mathrm{D}=\mathrm{Dedicating}$ the thesis)

As figure 2 shows, in sub-moves of the $\mathrm{PhD}$ acknowledgment texts, like those of MA corpus, relational processes are relatively highest in frequency. In acknowledgment texts of $\mathrm{PhD}$ corpus, material processes are most intensively used in TR step as in:

32). ... Bogotá, who made my grant possible, and for their believing that I could do it. (NSEPT2)

According to figure, mental processes are highly used in TM step as in:

33). I wish to give my warmest devotion to my parents for the things that I remember about their kindness and for the thing that I do not or perhaps cannot (IPT10).

As figure indicates, verbal processes employed in sub- moves of $\mathrm{PhD}$ acknowledgment texts, like those of MA ones, are found to be relatively more frequent in TA step as in:

34). First and for most, I would like to express my deepest and sincerest gratitude to my supervisor professor X. (IPT4)

Finally, Existential processes employed in sub- moves of $\mathrm{PhD}$ acknowledgments, like those of MA ones, are lowest in frequency as in:

35). There are many individuals who enter and exit one's life. (NSEPT8)

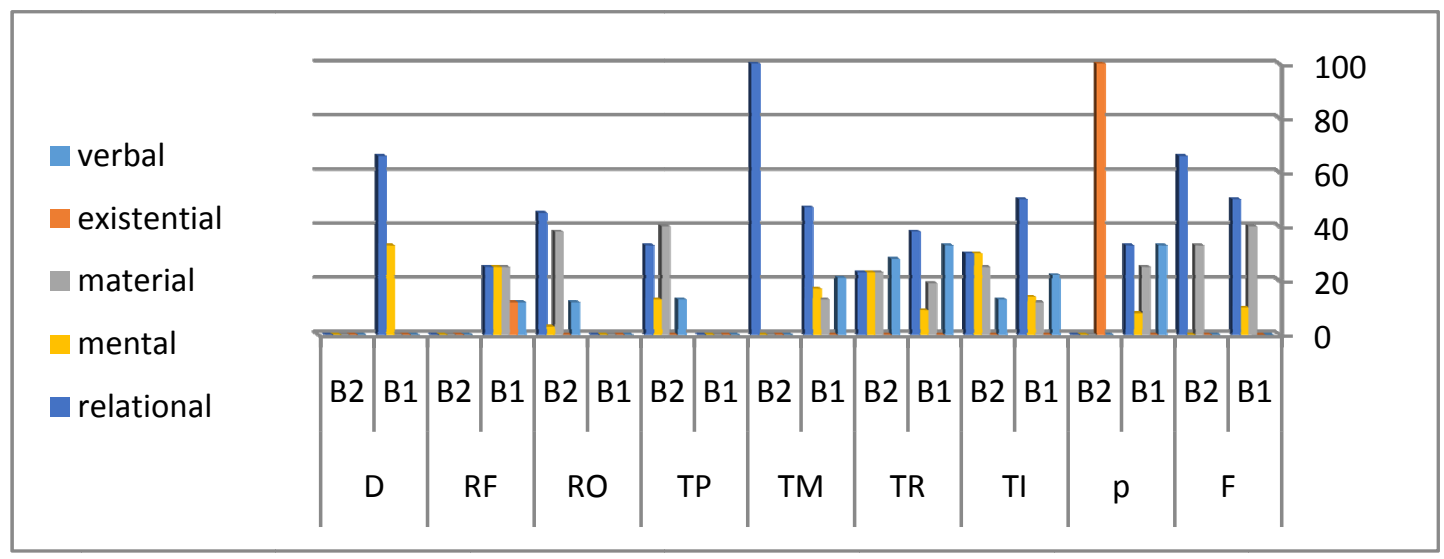

Figure 3. Distribution of process types in book acknowledgments

(B1= Iranian Book; B2= NSE Book; FM= Framing Move; P=Presenting; TI=Thanking for Individual contribution; $\mathrm{TR}=$ Thanking for Resources; $\mathrm{TM}=$ Thanking for Moral support; $\mathrm{RO}=$ Requesting for omissions; $\mathrm{RF}=$ Requesting for feedback; $\mathrm{D}=$ Dedicating the thesis) 
As figure 3 indicates, relational processes of books, like those of theses, are relatively the highest in frequency. In the sub-moves of these acknowledgment texts, material processes are most intensively used in TP step in native corpus as in:

36). The author and publisher are grateful to those who have given permission to reproduce the following extracts and adaptations of copyright material. (NSEB2)

According to figure, mental processes in these texts are relatively used more in frequency in TI step of Native corpus

37). Henry Widdowson read a number of chapters with his usual critical acumen. Three other reviewers kindly accepted my invitation to read specific chapters. (NSEB1)

As figure indicates, verbal processes employed in sub-moves of book acknowledgment texts, are found to be relatively more frequent in TR step as in:

38). Finally, I would like to thank the University of Auckland for awarding me a research fellowship grant to complete the work on the book. (NSEB1)

Finally, existential processes employed in these texts, like those of theses, are high in frequency in $\mathrm{P}$ step especially in Native corpus as in:

39). There have been many inputs into the writing of this book. (NSEB1)

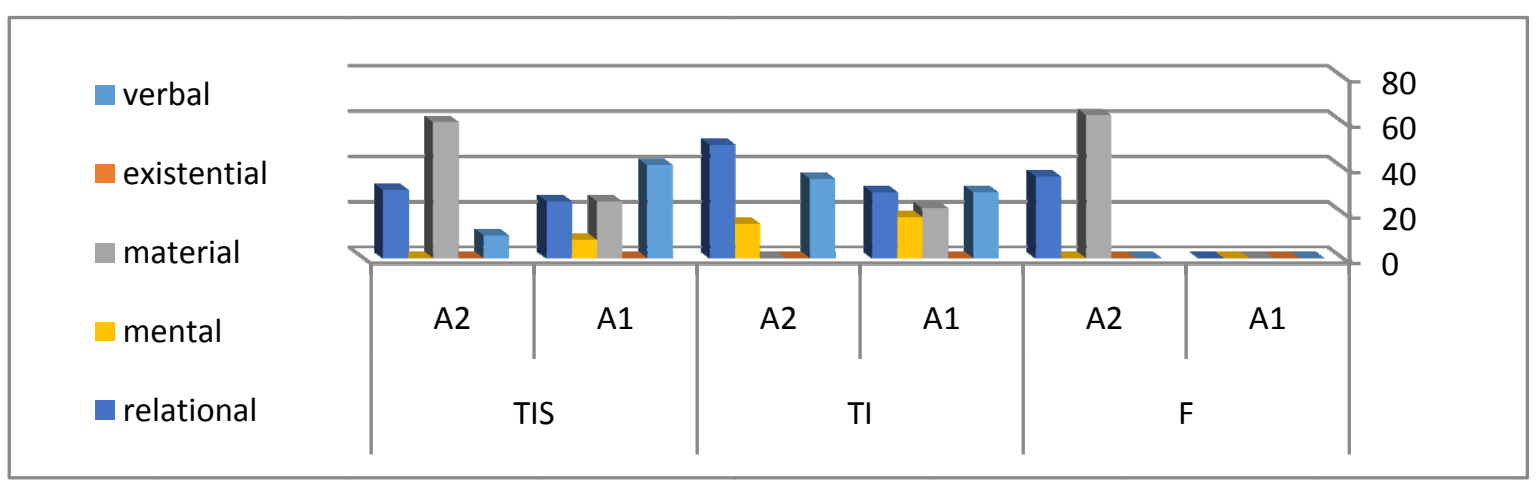

Figure 4. Distribution of process types in article acknowledgments

(A1=Iranian Article; A2=NSE Article; $\mathrm{F}=$ Framing move; $\mathrm{TI}=$ Thanking for individual contribution; TIS=Thanking for institutional support)

As figure 4 indicates, relational processes employed in sub-moves of article acknowledgments, unlike those of theses \& books, are not highest in frequency. In fact, in this genre, material processes are highest in frequency in FM \& TIS step in Native corpus as in:

40). I would like to gratefully acknowledge two organizations whose funding made it possible for me to conduct the necessary research. This work was supported in part by the National Science Foundation as well as fellowships and grants from the University of Chicago Humanities Division. (NSEA5)

41). She and the author presented the initial findings of this study at the Conference on College Composition and Communication held in 2005, in San Francisco. (NSEA1)

And verbal processes intensively used in TIS in Iranian corpus as in:

42). We gratefully acknowledge the project reported here was supported by a grant-in-aid of research From Ferdowsi University of Mashhad in 2011 (IA6).

As figure indicates, mental processes are employed in low frequency in TI step of article acknowledgments as in:

43). First and foremost, I would like to thank Beyza Bjorkman for all her helpful ... (NSEA4)

The analysis of ideational metafunction reveals that unlike thesis acknowledgments in which relational processes were highest in frequency, material processes and verbal processes were relatively highest in frequency in book \& article acknowledgments. 


\subsubsection{Analysis of the Textual Metafunction}

Grammatically, textual metafunction at the clausal level enjoys Theme. Theme functions as the "starting point for the message" (M. A. K. Halliday, 1985, p. 39), the element which the clause is going to be "about" has a crucial effect in orienting listeners and readers.

\subsubsection{Generic Thematic Choice}

In the textual analysis, all the identified sub-moves of acknowledgment texts are studied in terms of the thematic system. The following figures provide percentages of topical (marked \& unmarked), textual, and interpersonal themes employed in all sub-moves of acknowledgment texts in four corpora.

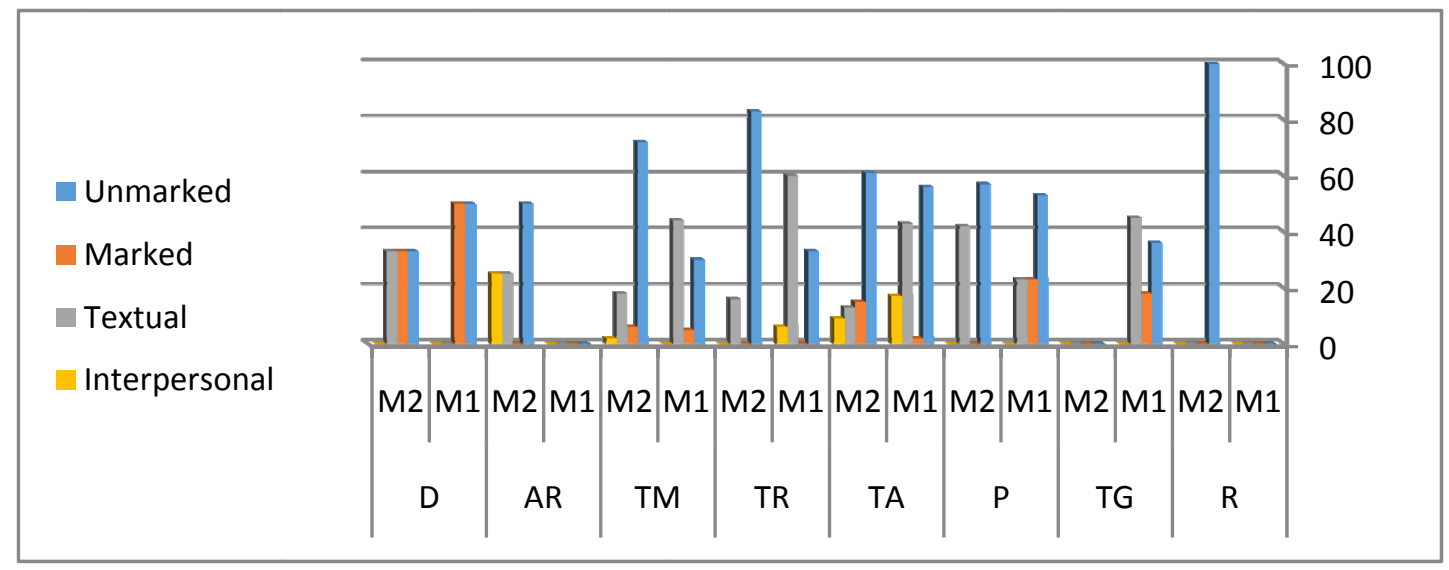

Figure 5. Distribution of themes in MA acknowledgments

As figure 5 indicates, the thematic choices of both NSE and Iranian in MA acknowledgments configure in a similar fashion, with unmarked theme being highest in frequency as in:

44). I would like to express my thankful expressions to $d r$. x. ... (IMT6)

45). Thanks go first to Detmar Meurers, who introduced me to. ... (NSEMT5)

Among the four major types of themes, although textual theme forms the second largest group, they are employed with more frequency by Iranian students as in:

46). First and foremost, I would like to thank Dr. X for ... (IMT10)

When compared to textual themes, interpersonal themes are used in smaller numbers. They are used in TA \& TR steps of MA acknowledgments. Since these steps were influenced by the personal views or emotions of the writer. It can be claimed they were more interactive in nature than other steps as in:

47). On a personal level, I would like to express my heartfelt thanks to my family.( IMT4)

48). Laura Wagner has helped me not only see the deeper questions relating to grammar... (NSEMT5).

"Marked themes", unlike an unmarked theme that shows a grammatical subject and forms the point of departure, employs a technique that front other information. It uses two main context frames for this purpose: Prepositional and Adverbial Phrases, and Subordinate Clauses and Nonfinite Clause (Gosden, 1992, p. 211).Marked themes are intensively used in D step as in:

49). For her generous indulgence, I lovingly dedicate this dissertation to my mother. (IMT7) 


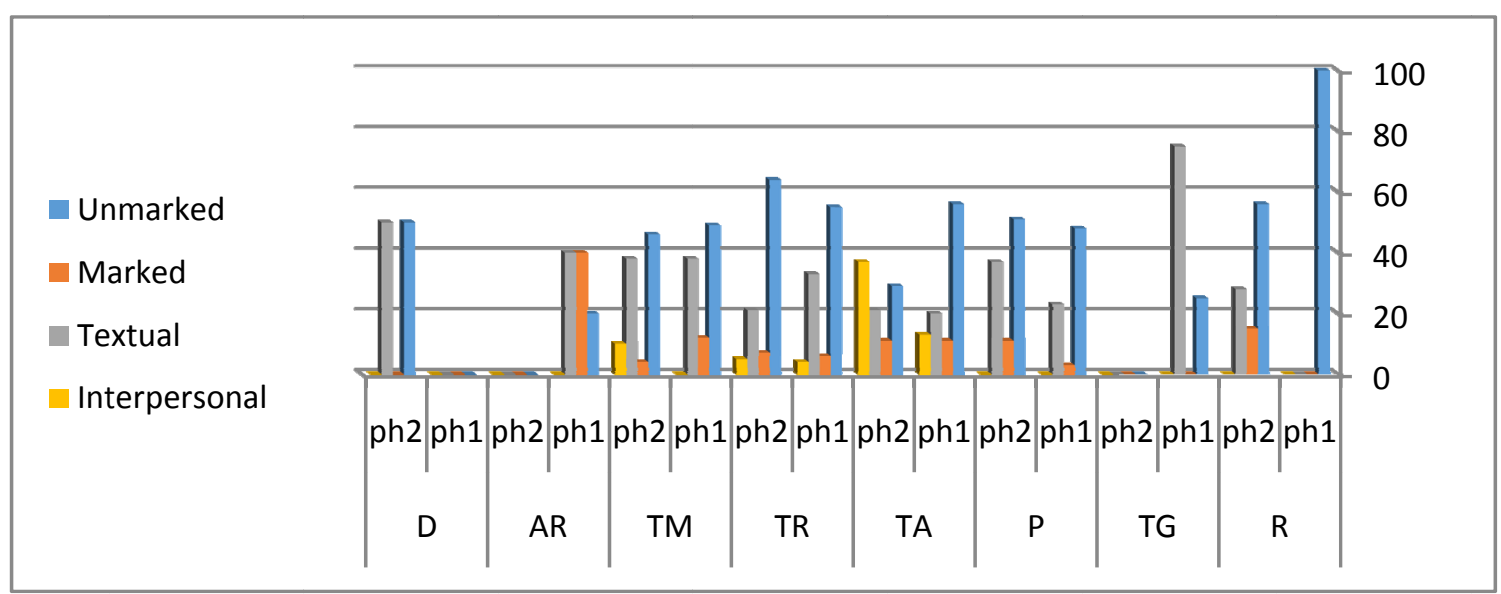

Figure 6. Distribution of themes in $\mathrm{PhD}$ acknowledgment

As figure 6 indicates, the thematic choices of both NSE and Iranian in PhD acknowledgments, like those of MA acknowledgments, configure in a similar fashion, with unmarked theme being highest in frequency as in:

50). I am eternally grateful to my parents, and my husband. ... who have supported me with patience and encouragement. (IPT5)

Textual theme employed in sub-moves of PhD acknowledgments, like those of MA acknowledgments, forms the second largest group. They are intensively used in TG step of Iranian corpus as in:

51). First of all, I should thank God who listened to my desire of learning and helped ... (IPT8)

As figure shows, interpersonal themes employed in sub-moves of $\mathrm{PhD}$ acknowledgments are intensively used in TA step in Native corpus as in:

52). Aaron Dinkin deserves special mention as a constant source of inspiration and collaboration. (NSEPT6)

According to figure, marked themes are intensively used in AR step of Iranian corpus as in:

53). For any shortcoming, to one to blame is only me. (IPT4)

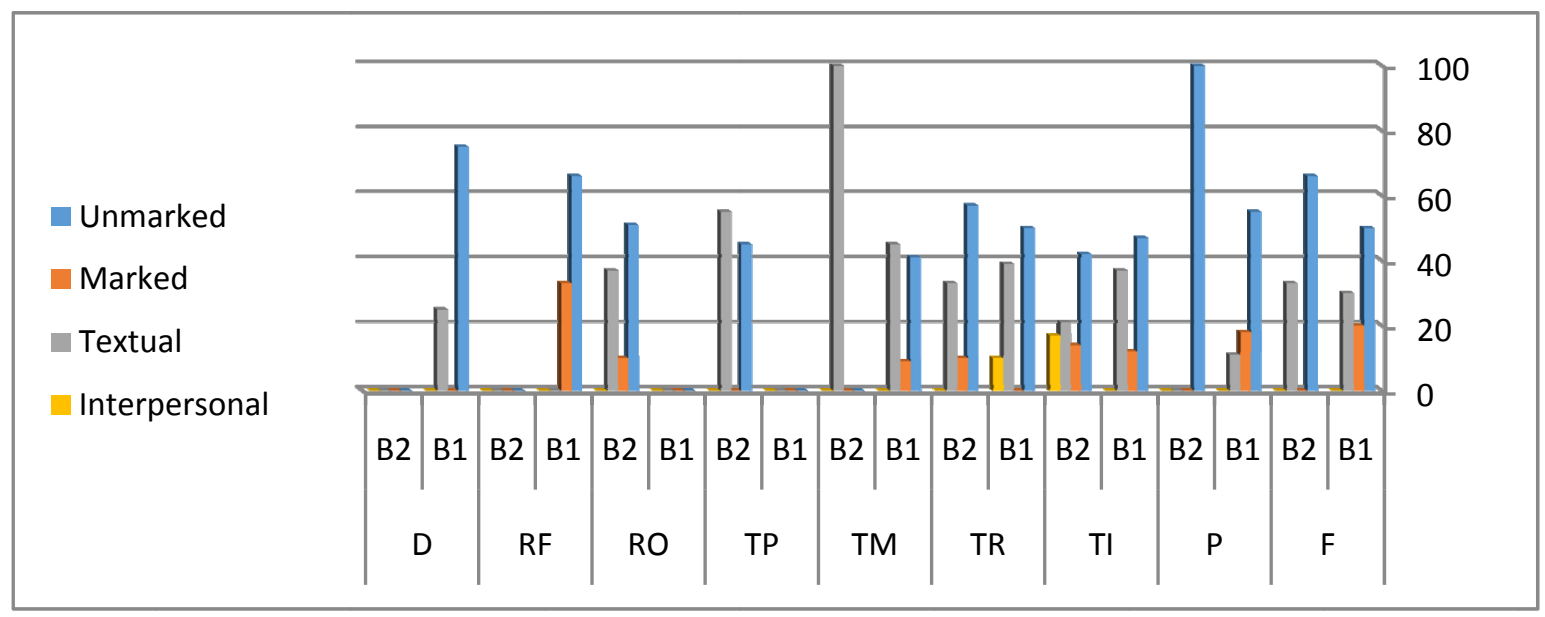

Figure 7. Distribution of themes in book acknowledgments

As figure7 indicates, the thematic choices of both NSE and Iranian in book acknowledgments, like those of Theses acknowledgments, configure in a similar fashion, with unmarked theme being highest in frequency as in:

54). I am indebted to the comments provided by various readers of the first draft. (NSE book)

Textual theme employed in sub-moves of book acknowledgments, like those of Theses acknowledgments, forms the second largest group. They are intensively used in TM step as in: 
55). Last but not least, I need to thank my family who have always been a source of encouragement and support. (Iranian book)

As figure shows, interpersonal themes employed in sub-moves of book acknowledgments are used in TI step in Native corpus as in:

56). Merril Swain commented in detail on chapters 4, 5 ... (NSE book).

According to figure, marked themes are intensively used in AR step of Iranian corpus as in:

57). In writing this book, I benefited from advice, support and encouragement given directly or indirectly from many people. (Iranian book)

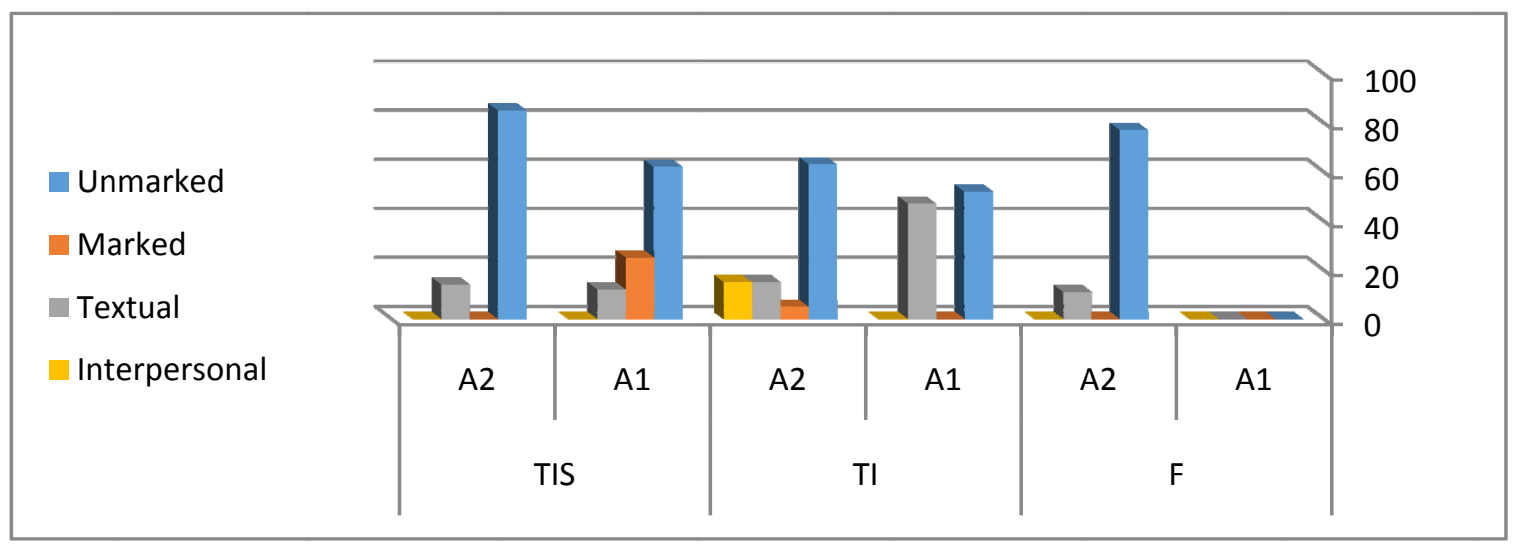

Figure 8. Distribution of themes in articles acknowledgments

As figure 8 indicates, the thematic choices of both NSE and Iranian in article acknowledgments, like those of Theses \& book acknowledgments, configure in a similar fashion, with unmarked theme being highest infrequency as in:

58). I am grateful to Richard Andrews, Ron Carter, Viv Ellis ... (NSEA6)

Textual theme employed in sub-moves of article acknowledgments, like those of Theses \& book acknowledgments, forms the second largest group. They are intensively used in TI step of Iranian corpus as in:

59). Also we appreciate the efforts of the anonymous reviewers of this article. (IA8)

As figure shows, interpersonal themes employed in sub-moves of article acknowledgments are used in TI step in Native corpus as in:

60). Anne Beaufort was especially supportive and encouraging as Associate Director ... (NSEA1)

According to figure, marked themes are intensively used in TIS step of Iranian corpus as in:

61). without which this research would not have been possible. (IA7)

As findings of this part show, while Iranian writers used a higher amount of textual themes in Thanking for individual step of $\mathrm{PhD}$, books, and article acknowledgments, NSE writers employed more interpersonal themes. This difference might suggest that Thanking for individual step employed in NSE corpus is more interactive in nature than the Iranian ones.

\subsubsection{Analysis of the Interpersonal Metafunction}

Grammatically, interpersonal metafunction at the clausal level enjoys Mood. Mood is concerned with the topic of information or service and whether it is giving or demanding. The interpersonal metafunction concentrates on social roles and relations through formality degree, pronouns, clausal mood (whether declarative, imperative or interrogative), etc. (Thompson, 2003) In association with the mood system, the use of adjuncts is also considered in interpersonal metafunction analysis. Moreover, a closer study of interactant pronouns also falls within the scope of the interpersonal analysis.

\subsubsection{Mood in Declarative Clauses}

The order Subject + Finite establishes the mood as declarative. Since clauses written in acknowledgment texts of our corpus are just declarative clauses so the following figures provide percentages of three types of declarative clauses (full declarative, Elliptical declarative, and inverted declarative) employed in all sub-moves of 
acknowledgment texts.

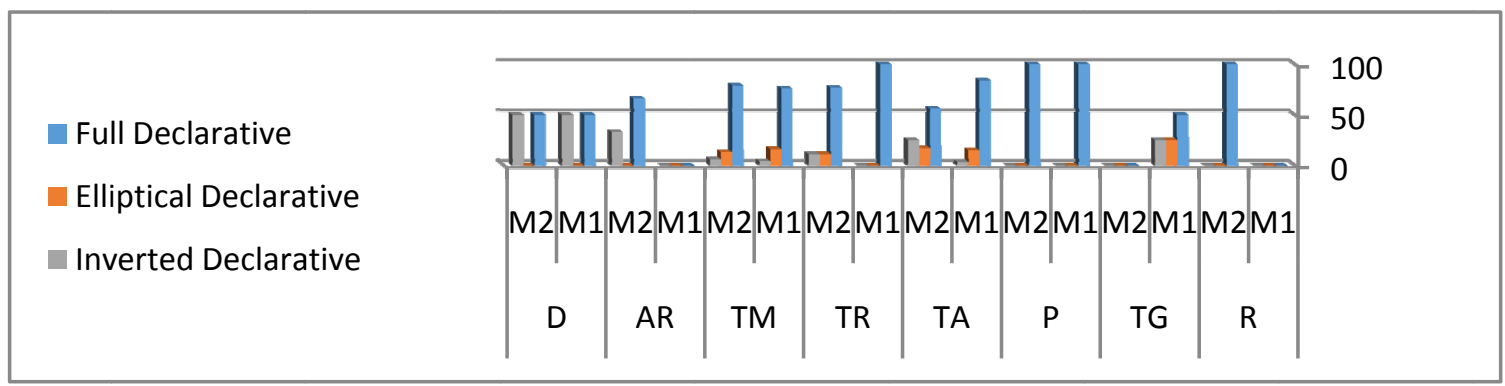

Figure 9. Distribution of mood types in MA acknowledgments

As figure 9 indicates, the number of full declarative clauses of MA acknowledgments is the highest in MA acknowledgments.

The coexistence of elliptical and inverted declarative clauses substantiates the multifunctional organization of the clause, for the interrelated options made in the MOOD system map onto the textual structuring of the clause. In the elliptical and inverted form of declarative clauses, some clause constituents are pushed forward and are thus made "marked" or "thematic" in the textual organization as in:

62). To Dr. Tirupalavanam Ganesh, my dissertation committee member, thank you for your kindness and motivational support. (NSEMT8)

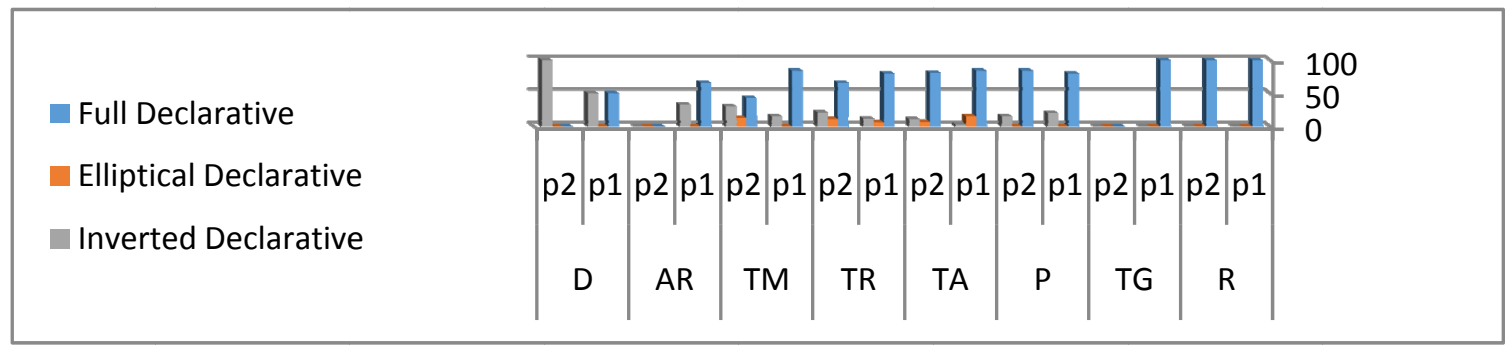

Figure 10. Distribution of mood types in $\mathrm{PhD}$ acknowledgments

As figure 10 indicates, the number of full declarative clauses of PhD acknowledgments, like those of MA acknowledgments, is the highest in $\mathrm{PhD}$ theses acknowledgments.

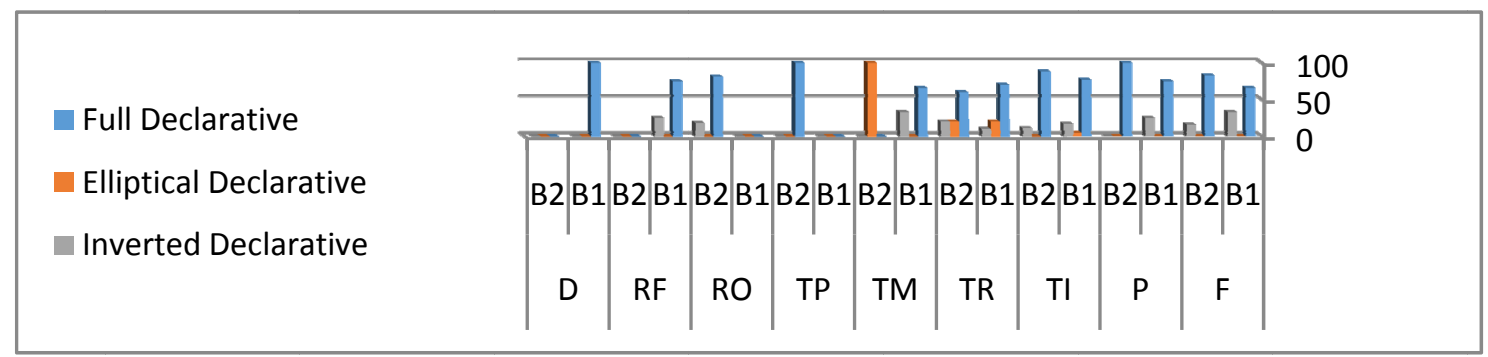

Figure 11. Distribution of mood types in book acknowledgments

As figure 11 indicates, the number of full declarative clauses of book acknowledgments, like those of theses acknowledgments, is the highest in this corpus. 


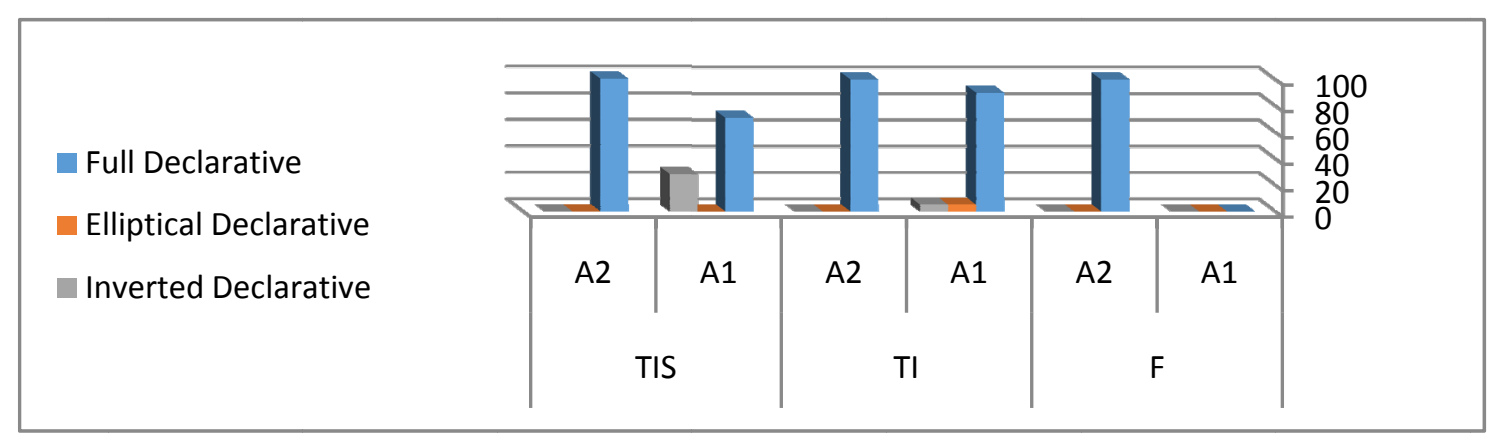

Figure 12. Distribution of mood types in article acknowledgments

As figure 12 indicates, the number of full declarative clauses of article acknowledgments, like those of theses \& book acknowledgments is high in two corpora.

The domination of the declarative MOOD choice in the four corpora reveals that the possibility of feedback between the author and his audience is non-existent in acknowledgment texts.

\subsubsection{Types of Adjuncts}

The following figures provide percentages of different types of adjuncts employed in all sub-moves of acknowledgment texts.

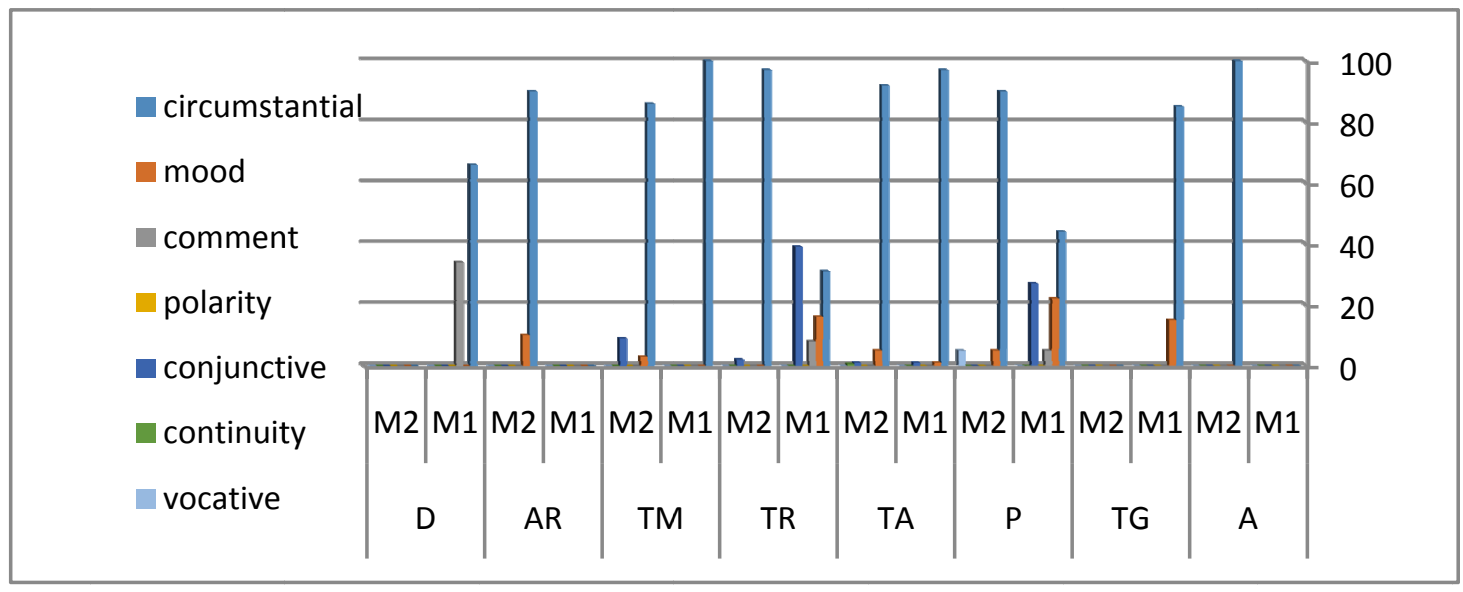

Figure 13. Distribution of adjunct types in MA acknowledgments

As figure 13 indicates, in MA acknowledgments although the dense population of circumstantial adjuncts found in both NSE and Iranian corpus, there are differences regarding the use of conjunctive, mood, and comment adjuncts between two corpora. While, the number of the adjuncts is high in Iranian corpus, it is slightly low in Native corpus.

According to figure, the higher frequency of Mood adjuncts in Iranian corpus reveals the extent to which language can be modified by the adjunctive units of lexico-grammar and emphasize force or writer's certainty in proposition as in:

63). This study could not have never been completed without the help and support ... (IMT7)

Also the greater population of comment adjuncts indicates the writer's tendency to intervene through the insertion of attitudinal elements expressing value judgments and attitude as in:

64). Above all, dear God, thank you for the faith, strength, patience, without which I could not survive even a second. (IMT1)

Conjunctive adjuncts are helpful in assisting readers to process written texts by expressing semantic relation between main clauses. These adjuncts are used more frequently by Iranian students as in:

65). In addition, I would like to thank ... (IMT7) 
According to figure, the vocative and continuity adjuncts are only employed in low frequency by NSE students which imply a more interactive style of their writing as in:

66). My supervisor, you have always been an inspiration to me. (NSEMT9)
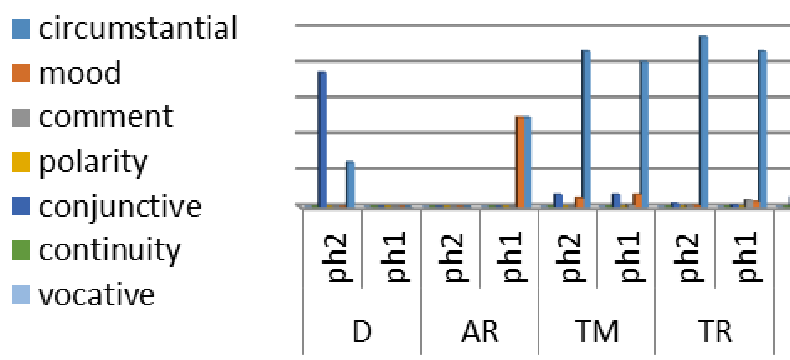

Figure 14. Distribution of adjunct types in PhD acknowledgments

As figure 14 indicates, there is a dense population of circumstantial adjunct in $\mathrm{PhD}$ acknowledgments in. But, unlike MA thesis acknowledgments, conjunctive, mood, and comment adjuncts relatively distribute in a similar pattern in both NSE and Iranian corpus. According to figure, the vocative and continuity adjuncts of PhD acknowledgments, like those of MA ones, are only employed in low frequency by NSE students as in:

67). Alas, there are far too many to thank. (NSEPT5)
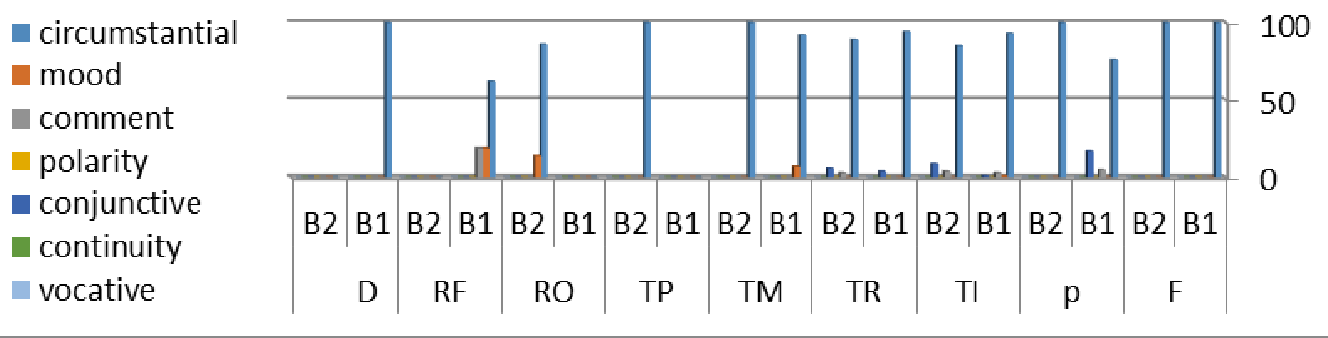

Figure 15. Distribution of adjunct types in book acknowledgments

As figure 15 indicates, there is a dense population of circumstantial adjuncts in book acknowledgments. But, unlike MA thesis acknowledgments, conjunctive, mood, and comment adjuncts relatively distribute in a similar pattern in both NSE and Iranian corpus.

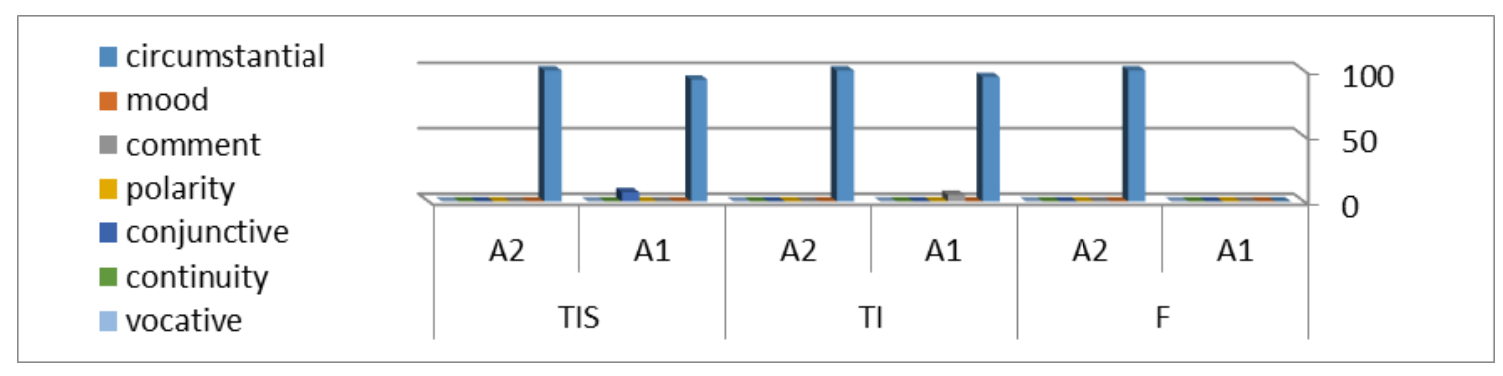

Figure 16. Distribution of adjunct types in article acknowledgments

As figure 16 indicates, although, there is a dense population of circumstantial adjunct in article acknowledgments, there are differences regarding the use of comment and conjunctive adjuncts in which these adjuncts are employed only in low frequency in Iranian corpus as in:

68). I am grateful to Dr. A. Kaviani who kindly read the first draft of this paper. (IA10)

69). Moreover, our sincere thanks go to Dr. Gavin Brown for allowing us to use his instrument in Iran. (IA7) 
The results of this part reveal some cross-cultural differences regarding the use of adjuncts. The first difference was that, the number of conjunctive and mood adjuncts is high in MA \& article acknowledgments of Iranian corpus.The another difference was that, the vocative and continuity adjuncts were only employed in low frequency by NSE students in MA \& PhD acknowledgment texts which imply a more interactive style of their writing.

\subsubsection{Percentage and Type of Interactant Pronouns}

Interpersonal distance refers to the distance between speaker and addressee that can be determined by measuring the type and frequency of interactant references (Eggins et al., 1993). The following figures provide percentages of interactant pronouns employed in all sub moves of acknowledgment texts in two corpora.

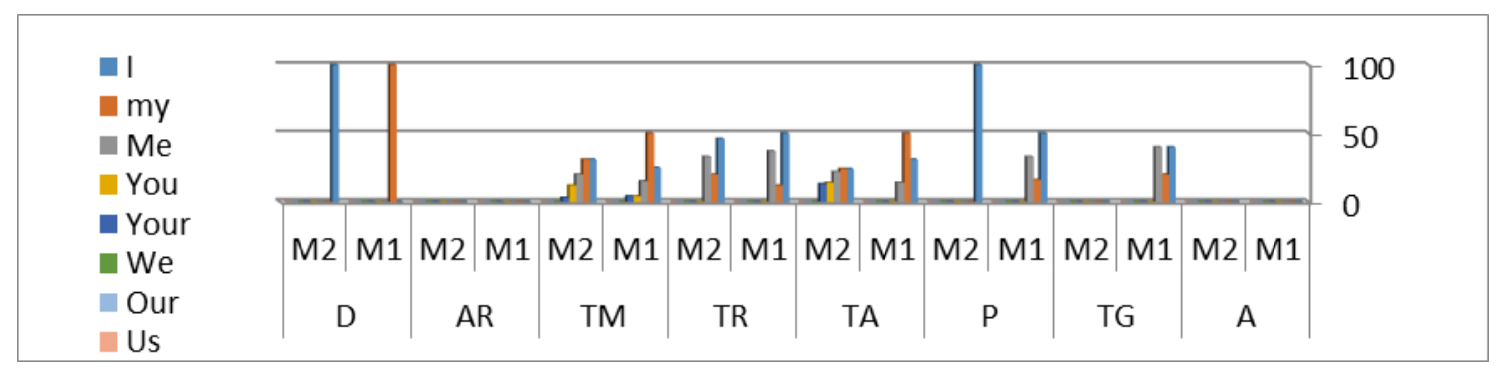

Figure 17. Distribution of interactant pronoun in MA acknowledgments

As figure 17 indicates, there is frequent use of interactant systems. Thus, it can be claimed that very close interpersonal distance can be observed in these acknowledgment texts. But, despite these similarities, NSE and Iranian corpus have differences regarding the use of the type of these interactant references. While the frequency of the pronouns "I" \& "my" are relatively high in both corpora, Native corpus has a higher frequency of the personal pronoun "you" than Iranian one. This is probably because the gratitude in native corpus frequently is done with Direct Thanking expressions as in:

70). To Dr. Tirupalavanam Ganesh, my dissertation committee member, thank you for your kindness and motivational support. You helped me to remember that I was more than capable of completing this work. (NSEMT8)

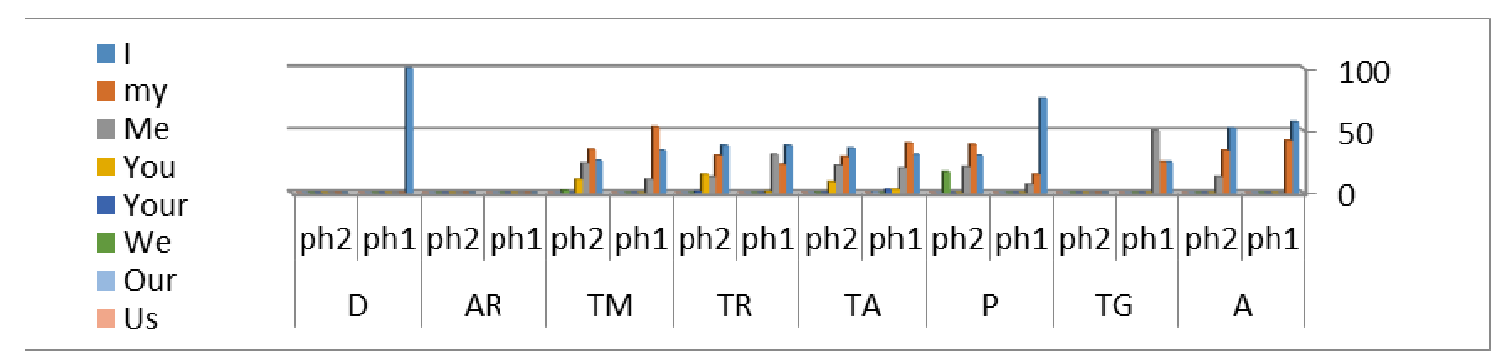

Figure 18. Distribution of interactant pronoun in $\mathrm{PhD}$ acknowledgments

As figure 18 indicates, there is frequent use of interactant systems. Like MA acknowledgments, in PhD texts NSE corpus has a higher frequency of the personal pronoun "you" than Iranian one.

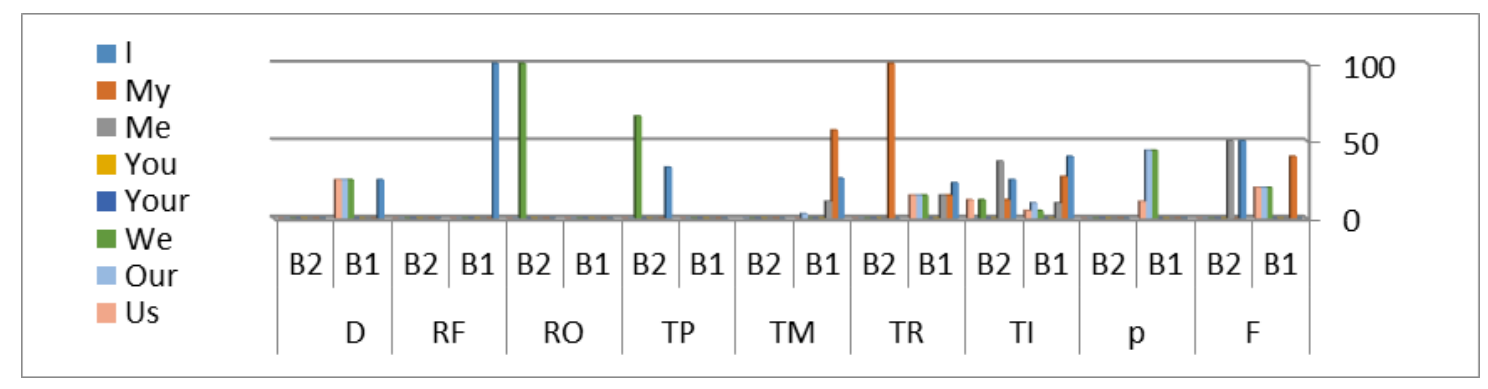

Figure 19. Distribution of interactant pronoun in book acknowledgments 
As figure 19 indicates, there is frequent use of interactant systems. In addition to pronouns "I" \& "my", personal pronouns "we" \& "our" are employed more frequently in book acknowledgments which implies commonality against individual work.

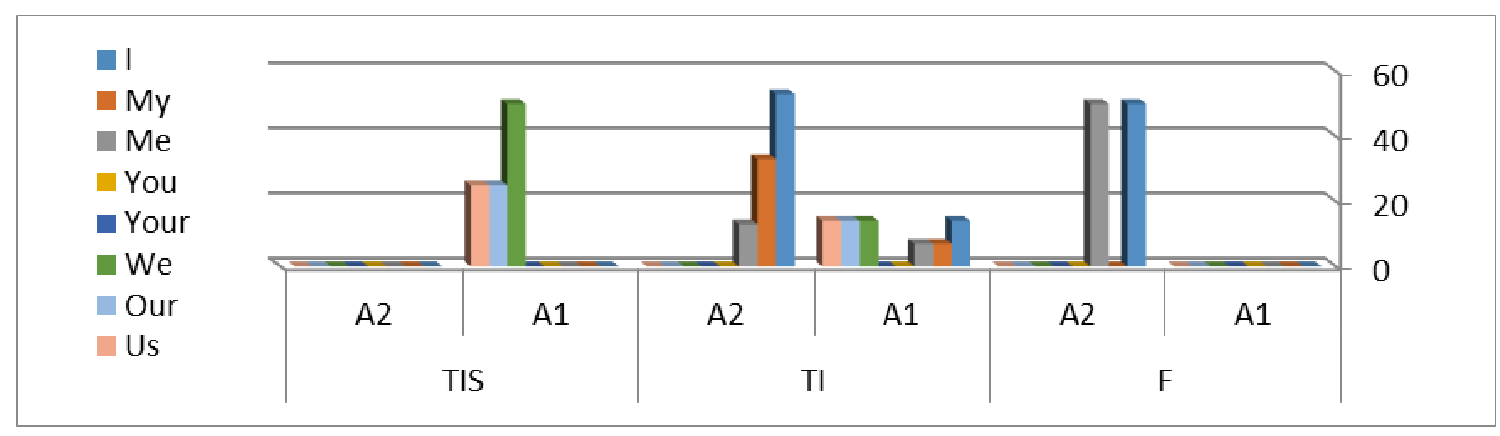

Figure 20. Distribution of interactant pronoun in article acknowledgments

As figure 20 indicates, like book acknowledgments, there is frequent use of interactant systems especially personal pronouns of "we" \& "our" except in TIS step of NSE corpus. It is probably because that native writers use descriptions devoid of appreciation for institution supports as in:

\section{1). This work was supported by a grant from the Economic and Social Research Council. (NSEA7)}

According to results, the cross-cultural difference was that, in $\mathrm{MA} \& \mathrm{PhD}$ acknowledgments, while the frequency of the pronouns "I" \& "my" are relatively high in both corpora, NSE corpus has a higher frequency of the personal pronoun "you". This is probably because that gratitude in native corpus frequently is done with Direct Thanking expressions.

\section{Conclusion}

This research examined acknowledgments of various genres (Textbooks, articles, MA \& PhD these) written by Iranian and Native Speakers of English to provide a descriptive contextual framework of the factors that are thought to be responsible for the possible cross-generic and cross-cultural variations through genre analysis and multifunctional analysis.

The first stage of the analysis, in which the investigation of the generic structure of acknowledgments is done, revealed that this genre is constituted of a main "Thanking" Move framed by two optional "Reflecting" and "Announcing" moves in Theses, two optional "framing" and "Announcing" moves in textbooks, and one optional "Framing" move in research articles. Despite observing the "Thanking move" in acknowledgments of all genres, differences were found in the type and frequency of constituent steps used to realize the "Thanking" move. For example, Acknowledgements in journal articles and books, are intended, more critically, for the "strong networks of association between researchers (Hyland, 2003, p. 246). These differences might reveal the fact that the shape of genre and its internal structure are determined by the communicative purpose it is going to serve. In fact, these cross-generic differences can be understood by reference to the multiple participant networks which influence and shape the schematic structure of the these genres. Thus, scientific knowledge should not be treated independently from the participants of discourse.

In multifunctional analysis phase, the analysis of ideational metafunction reveals that unlike thesis acknowledgments in which relational processes were highest in frequency, material processes and verbal processes were relatively highest in frequency in book \& article acknowledgments. This seems to imply that the authorial roles, individual purposes, and writer-reader relationships in thesis acknowledgements are very different from the choices available in research genres, allowing writers to express themselves unreservedly and sincerely (Hyland \& Tse, 2004).The noticeable finding of interpersonal metafunction analysis was that in research genre acknowledgments (books \& articles) in addition to pronouns "I" \& "my", personal pronouns "we" \& "our" are employed more frequently which might reveal the fact that research genre acknowledgments are more concerned with linking articles to the public sphere of academic presentation and publications which imply the collaborative dimension of research in contrast to the principle of clear-cut authorship (Giannoni, 2002). Moreover, not employing the interactant pronouns by NSE writers in TIS step of research acknowledgments and the significant use of authorial pronouns in subject position represent an interesting rhetorical contrast to the extensive use of "I" \& "we" pronouns in the theses acknowledgments. This is in line with Giannoni's (2002) findings of a preference 
for I-avoidance in research article acknowledgements, where writers made extensive use of the author, a more impersonal form which serves to distance writers from their thanks. In addition to these cross-generic differences, the results of this study also revealed cross-cultural differences both in genre analysis and multifunctional analysis. Therefore, it can be concluded that, the analysis of the genre continuum designed for the purpose of this study reflects how the contextual, cultural, and institutional forces influence the production and reception of academic genres.

Since the data examined in this study comprised 80 acknowledgment texts of academic writing. In order to claim valid generalizability of the results the corpus examined in future studies can be enriched by adding data.

\section{References}

Al-Ali, M. (2005). Communicating messages of solidarity, promotion, and pride in death announcements genre in Jordanian newspapers. Discourse and society, 16, 5-31. http://dx.doi.org/10.1177/0957926505048228

Al-Ali, M. N. (2010). Generic patterns and socio-cultural resources in acknowledgements accompanying Arabic PhD dissertations. Pragmatics, 20(1), 1-26.

Bawarshi, A. (2000). The genre function. College English, 62(3), 335-360. http://dx.doi.org/10.2307/378935

Bazerman, Ch. (1997). The life of genre, the life in the classroom. In W. Bishop, \& H. Ostrom (Eds.), Genre and Writing: Issues, Arguments, Alternatives (pp. 19-26). Portsmouth: Boynton/Cook.

Berkenkotter, C., \& Huckin, T. N. (1995). New values in scientific journal articles. In C. Berkenkotter, \& T. Huckin (Eds.), Genre knowledge in disciplinary communication. Hillsdale, New Jersey: Lawrence Erlbaum.

Bhatia, V. K. (1993). Analysing genre: Language use in professional settings. London: Longman. http://dx.doi.org/10.1017/s0272263100013668

Campbell, K., \& Jamieson, K. H. (1978). Form and genre: Shaping rhetorical action. Falls Church: Speech Communication Assoc.

Cheng, W. (2012). A contrastive study of master thesis acknowledgements by Taiwanese and North American students. Open Journal of Modern Linguistics, 2(1), 8-17. http://dx.doi.org/10.4236/ojml.2012.21002

Christie, F. (1988). Genres as choice. In J. Reid (Ed.), The place of genre in learning: Current debates (pp. 22-34). Gee long: Deakin University.

Coffin, C. (2001). Theoretical approaches to written language: A TESOL perspective. In A. Burns, \& C. Coffin (Eds.), Analyzing English in a global context (pp. 93-122). London: Routledge.

Eggins, S., Martin, J. R., \& Wignell, P. (1993). Register analysis: Theory \& practice. London: Pinter.

Fairclough, N. (1995). Critical discourse analysis. The critical study of language. London: Longman. http://dx.doi.org/10.1017/s0142716400010973

Giannoni, D. S. (2002). Worlds of gratitude: A contrastive study of acknowledgment texts in English and Italian research articles. Applied Linguistics, 23(1), 1-31. http://dx.doi.org/10.1093/applin/23.1.1

Giannoni, D. S. (2006). Book acknowledgements across disciplines and texts. In K. Hyland, \& M. Bondi (Eds.), Academic discourse across disciplines (pp. 151-175). Berlin: Peter Lang.

Halliday, M. A. K. (1978). Language as social semiotic: The social interpretation of language and meaning. London: Arnold. http://dx.doi.org/10.1017/s004740450000782x

Halliday, M. A. K. (1985). An introduction to functional grammar. London: Arnold.

Halliday, M. A. K. (1987). Language as social semiotic. London: Edward Arnold.

Halliday, M. A. K., \& Hasan, R. (1985). Language, context, and text: Aspects of language in a social-semiotic perspective. Geelong: Deakin University Press.

Halliday, M. A. K., \& Martin, J. R. (1993). Writing science: Literacy and discursive power. London Washington, D.C: The Falmer Press. http://dx.doi.org/10.4324/9780203209936

Halliday, M. A. K., \& Matthiessen, C. (2004). An introduction to functional grammar (3rd ed.). London: Arnold. http://dx.doi.org/10.2307/414947

Halliday, M. A. K. (1994). Language as social semiotic. Language and literacy in social practice. London: Arnold.

Hofstede, G. (2001). Culture's consequences: Comparing values, behaviours, institutions and organisations 
across nations (2nd ed.). London: Sage Publications.

Hyland, K. (2003). Dissertation acknowledgements: The anatomy of a cinderella genre. Written Communication, 20, 242-268. http://dx.doi.org/10.1177/0741088303257276

Hyland, K. (2004). Graduates' gratitude: The generic structure of dissertation acknowledgements. English for Specific Purposes, 23, 303-324. http://dx.doi.org/10.1016/s0889-4906(03)00051-6

Hyland, K., \& Tse, P. (2004). "I would like to thank my supervisor": Acknowledgements in graduate dissertations. International Journal of Applied Linguistics, 14(2), 259-275. http://dx.doi.org/10.1111/j.1473-4192.2004.00062.x

Hyon, S. (1996). Genre in three traditions: Implications for ESL. TESOL Quarterly, 30(4), 693-722. http://dx.doi.org/10.2307/3587930

Jamieson, K. M. (1975). Antecedent Genre as Rhetorical Constraint. Quarterly Journal of Speech, 61, 406-415. http://dx.doi.org/10.1080/00335637509383303

Kress, G. (1988). Genre in a Social Theory of Language: A Reply to John Dixon. In I. Reid (Ed.), The place of genre in learning: Current debates (pp. 35-45). Geelong: Deakin University.

Lasaky, F. (2011). A contrastive study of generic organisation of doctoral dissertation acknowledgements written by native and non-native (Iranian) students in applied linguistics. The Modern Journal of Applied Linguistics, 3(2), 175-199.

Martin, J. R. (2009). Genre and language learning: A social semiotic perspective. Linguistics and Education, 20, 10-21. http://dx.doi.org/10.1016/j.linged.2009.01.003

Martin, J. R., Matthiessen, C. M. I. M., \& Painter, C. (1997). Working with Functional Grammar. London: Arnold.

Medway, P. (1994). Language, learning, and “communication" in an architect's office. English in Education, 28, 3-13. http://dx.doi.org/10.1111/j.1754-8845.1994.tb01115.x

Miller, C. R. (1984). Genre as Social Action. Quarterly Journal of Speech, 70, 151-67. http://dx.doi.org/10.1080/00335638409383686

Morley, G. D. (1985). An Introduction to Systemic Grammar. Hong Kong: Macmillan.

Nwogu, N. K. (1997). The medical research paper: Structure and functions. English for specific purposes, 16(2), 119-138. http://dx.doi.org/10.1016/S0889-4906(97)85388-4

Russell, D. R. (1997). Rethinking genre in school and society: An activity theory analysis. Written Communication, 14(4), 504-554. http://dx.doi.org/10.1177/0741088397014004004

Shahriari, H. (2009). A Comparison of Genre: Biological Science Research Article Abstracts by Iranian and Native English-Speaking Scholars. The Asian ESP Journal, 5(2), 107-120.

Swales, J. M. (1990). Genre analysis. English in academic and research settings. Cambridge: Cambridge University Press.

Swales, J. M. (2004). The manuscript version of chapter seven of Research genres: Explorations and application. Cambridge: Cambridge University Press. http://dx.doi.org/10.1017/CBO9781139524827

Thompson, S. A. (2003). Functional Grammar. In W. Frawley (Ed.), Oxford International Encyclopedia of Linguistics (2nd ed.). Oxford: Oxford University Press.

Yang, W. (2012). Comparison of gratitude across context variations: A generic analysis of dissertation applied linguistics written by Taiwanese authors in EFL \& ESL contexts. International journal of applied linguistics and English literature, 1(5), 130-146. http://dx.doi.org/10.7575/ijalel.v.1n.5p.130

Yates, J., \& Orlikowski, W. (1992). Genres of organizational communication: A structural approach. Academy of Management Review, 17, 299-326. http://dx.doi.org/10.5465/amr.1992.4279545

Yu, M. (2003). On the universality of face: Evidence from Chinese compliment response behaviour. Journal of Pragmatics, 35, 1679-1710. http://dx.doi.org/10.1016/s0378-2166(03)00074-2 


\section{Appendix A}

\section{List of the MA Theses}

\section{- NSE writers}

NSEMT1. Bogdewiecz, S. (2007). Hard Science Linguistics and Nonverbal Communicative Behaviors: Implications for the Real World Study and Teaching of Human Communication. The University of Toledo.

NSEMT2. Crook, M. (2005). Improving cognitive/academic language proficiency of low achieving grade students: A catalyst for improving proficiency scores? Bowling Green State University.

NSEMT3. Freday, M. (2011). Strategic Listening: Examining the Efficacy of a Pedagogical Cycle Intended to Teach the Listening Process, Increase Metacognitive Awareness and Improve Comprehension. The College of Arts and Sciences of Ohio University.

NSEMT4. Hamrick, Ph. (2008). The effectiveness of cognitive grammar and traditional grammar in L1 pedagogy: an empirical test. Youngstown State University.

NSEMT5. Kenton, J. (2009). Prasing with local context. The Ohio State University.

NSEMT6. Nathan, R. (2007). Instant messaging communication: A quantititative linguistic analysis. Miami University Oxford, Ohio.

NSEMT7. Wherley, K. (2010). Standing on an Internet Soapbox: An Exploration of Language and Gender on Facebook. The University of Toledo.

NSEMT8. Wolfel, A. (2010). Analyzing Celebrity Gossip Blogs to Gain a Better Understanding of the Language Stereotype of Gay Men. The University of Toledo.

NSEMT9. Zallocco, R. (2011). Communication and Language Learning. The University of Toledo.

NSEMT10. Ziegler, N. (2007). Task Based Assessment: Evaluating Communication in the Real World. The University of Toledo.

\section{- Iranian writers}

IMT1. Hosseinian, F. (2010). The relationship between Academic self-concept of Iranian EFL Learner \& Their Academic Achivements. Tabriz Islamic Azad University, Tabriz.

IMT2. Kazemzadeh, H. (2010). A comparative Study of Grammatical Metaphor in Harry patter and its Persian translation. Tabriz Islamic Azad University, Tabriz.

IMT3. Khodabandehlou, R. (2011). A Needs-Based Evaluation of the Iranian EFL Institute textbooks of intermediate level: New headway and New interchange. Tabriz Islamic Azad University, Tabriz.

IMT4. Mousaie, S. (2011). An Investigation of Discourse Related to Gaza strip in pro- and anti-Israeli Media. Tabriz Islamic Azad University, Tabriz.

IMT5. Ravandi, R. (2011). The effect of Group work on promoting Iranian Male and Female Learners' Reading Comprehension Skill. Tabriz Islamic Azad University, Tabriz.

IMT6. Samei, H. (2010). The role of Journey in chorles Dickens' Great Expections an Twain's Adventures of Huckleberyfinn. Tabriz Islamic Azad University, Tabriz.

IMT7. Sepehran, H. (2011). The effect of Intertextuality on Iranian EFL Learners Critical Writing. Tabriz Islamic Azad University, Tabriz.

IMT8. Shojafarian, E. (2010). The effect of using Synonymy on Intermediate Iranian EFL Learners, Incidentals vocabulary. Tabriz Islamic Azad University, Tabriz.

IMT9. Shokri, A. (2011). The effect of Formal instruction of conjunctions and lexical ties on the Development of cohesion in EFL students' writing skill. Tabriz Islamic Azad University, Tabriz.

IMT10. Talebi, M. (2010). The relationship between Upper-Intermediate Iranian EFL learners' Reflectivity Style and Use of formulatic Expressions in News summary writing. Tabriz Islamic Azad University, Tabriz. 


\section{Appendix B}

\section{List of the PhD Theses}

\section{- NSE Writers}

NSEPT1. Wolf, M. A. (2008). Optimal Interleaving: Serial Phonology-Morphology Interaction. University of Massachusetts Amherst.

NSEPT2. Barletta, N. P. (2007). English Teacher in Colombia: Ideologies and Identities in Academic Writing. University of Arizona.

NSEPT3. Bunting, J. D. (2011). Exploring Sranan Syntax: Expressions of Uneqal Comparison in a Caribban English Creole. The University of Chicago, Illinois.

NSEPT4. Carpenter, H. (2008). A Behavioral and Electrophysiological Investigation of Different Aptitudes for L2 Grammar in Learners Equated for Proficie. Georgetown University, Washington, DC.

NSEPT5. Coste, R. L. (2009). Hyper Textual Ultra Structures: Movement and Containment in texts and Hypertexts. Texas A \& M University.

NSEPT6. Evanini, K. (2009). The Permeability Of Dialect Boundaries: A Case Study of The Region Surrounding Erie. University of Pennsylvania.

NSEPT7. Howald, B. S. (2011). The Transformation of Spatal Experience in Narrative Discourse. Graduate School of Arts and Sciences of Georgetown University.

NSEPT8. Kelly, J. (2012). Understanding the Role of Academic Language on Conceptual Understanding in an Introductory Materials Science and Engineering Course. Arizona State University.

NSEPT9. Looker, S. M. W. (2011). Enacting and Interrogating the Academic in Undergraduate Language and Literacy Practices. University of Illinois at Urbana-Champaign.

NSEPT10. Wolcott, T. P. (2010). Americans in Paris: A Discourse Analysis of Student Accounts of Study Abroad. University of California, Berkeley.

\section{- Iranian Writers}

IPT1. Golami, J. (2007). Reactive and Preemptive Language Related Episodes and Uptake in EFL Classes. Tabriz University, Tabriz.

IPT2. Hazer, F. (2008). The Impact of Interactional Feedback on Task-Based Oral Discourse. Tabriz University, Tabriz.

IPT3. Khoddami, F. (2011). Being a Female English Teacher: Narratives of Identities in the Iranian Academy. University of Exeter.

IPT4. Kuhi, D. (2010). An Exploration of Interpersonal resources in Academic Discourse. Islamic Azad University, Tabriz Branch, Tabriz.

IPT5. Mohamadian, Zh. (2008). An Exploration of types of forms in EFL classroom interactions. Tabriz University, Tabriz.

IPT6. Rasti, I. (2011). Involving the Reader in the Text: Engagement Markers in Native and Non-native Student Argumentative Essays. University of Liverpool.

IPT7. Razmjoo, L. (2011). Translation Quality and Awarene of Translation Theories. Tabriz University, Tabriz.

IPT8. Seifouri, N. (2010). SFL and ESP Genre Analysis of English Research Articles in Iranian and English-American Medical Journals: A Contrastive Study. University of Tehran, Tehran.

IPT9. Valizadeh, A. (2011). Autonomy and Autonomous language learning; Extra-Mural media in intra-mural language Learning: A constructivist Approach; Focus on form. Tabriz University, Tabriz.

IPT10. Yaghobi, M. (2007). Variability in L2: Exploring Gender Influence in Task-Prompted oral proficiency. Tabriz University, Tabriz.

Appendix C

List of textbooks

- Native Books

NSEB1. Ellis, R. (2003). Task-based Language Learning and Teaching. New York: Oxford University Press. 
NSEB2. Ellis, R. (2008). The Study of Second Language Acquisition. New York: Oxford University Press.

NSEB3. Fulcher, G., \& Davidson, F., Jr. (2007). Language Testing and Assessment. London: Routledge.

NSEB4. Hedge, T. (2005). Teaching and Learning in the Language Classroom. New York: Oxford University Press.

NSEB5. Hughes, A. (2003). Testing for Language Teachers. NewYork: Cambridge University Press.

NSEB6. Mitchell, R., \& Myles, F., Jr. (2004). Second Language Learning Theories. New York: Oxford University Press.

NSEB7. Radford, A. (2003). Introducing Functional Grammar. New York: Cambridge University Press.

NSEB8. Radford, A. (2009). Analyzing English sentences: A Minimalist Approach. New York: Cambridge University Press.

NSEB9. Richards, J. C., \& Renandya, W. A., Jr. (2002). Methodology in Language Teaching. New York: Cambridge University Press.

NSEB10. Halliday, M. A. K. (2003). On Language and Linguistics (J. Webster, Ed.). New York: Continuum.

\section{- Iranian Books}

IB1. Birjandi, P., Shahidi, H. R., \& Abdi, F. (2006). A New Approach to teaching Idiomatic Expressions and Slang. Tehran: Goyesh Publications.

IB2. Birjandi, P., \& Mosallanejad, P., Jr. (2009). Research Methods 1 \& 2 for the English Major Students. Tehran: Sepahan publications.

IB3. Bustamarte, F. (2001). Advanced Writing. Tehran: Samt Publications.

IB4. Niazi, N. (2004). Novel \& Interpretation: A Pragmatic Approach. Tehran: Rahnema Publications .

IB5. Rashtchi, M., \& Keyvanfar, A., Jr. (2007). ELT Quick 'n'Easy. Tehran: Rahnama Publication.

IB6. Saeidi, M. (2006). Multiple Intelligence-Based Focus on Form. Tabriz: Islamic Azad University of Tabriz Publications.

IB7. Shahbazi, M. (2010). A Practical Teaching Guide to English. Tehran: Publications.

IB8. Solti, M. (2010). The short Story. Tehran: Samt Publications.

IB9. Zareee, A. (2008). A Textbook of Languag Teaching Methods. Tehran: Jungle Publications.

Appendix D

\section{List of Research Articles}

\section{- Native Articles}

NSEA1. Denny, H. C. (2008). Dangerous liaisons: Reflections on a pilot project for state-mandated outcomes assessment of written communication. Assessing Writing, 13, 26-44.

NSEA2. Harwood, N. (2005). A corpus-based studies of self-promotional I and we in academic writing Across four disciplines. Journal of Pragmatics, 37, 1207-1231.

NSEA3. Hellermann, J., \&Vergun, A. (2007). Language which is not taught: The discourse marker use of beginning adult learners of English. Journal of Pragmatics, 39, 157-179.

NSEA4. Jenkins, J. (2011). Accommodating (to) ELF in the international university. Journal of Pragmatics, 43, 926-936.

NSEA5. Jones, P. E. (2007). Why there is no such thing a "critical discourse analysis". Language \& Communication, 27, 337-368.

NSEA6. Lefstein, A. (2009). Rhetorical grammar and the grammar of schooling: Teaching "powerful verbs" in the English National Literacy Strategy. Linguistics and Education, 20, 378-400.

NSEA7. Nation, K., Angell, Ph., \& Castles, A. (2007). Orthographic learning via self-teaching in children learning to read English: Effects of exposure, durability, and context. Journal of Experimental Child Psychology, 96, 71-84.

NSEA8. Plakans, L. (2008). Comparing composing processes in writing-only and reading-to-write test tasks. Assessing Writing, 13, 111-129. 
NSEA9. Spencer-Oatey, H. (2011). Conceptualising "the relational" in pragmatics: Insights from metapragmatic emotion and (im)politeness comments. Journal of Pragmatics, 43, 3565- 3578.

NSEA10. Walker, G. (2007). On the design and use of pivots in everyday English conversation. Journal of Pragmatics, 39, 2217-2243.

\section{- Iranian Articles}

IA1. Babaii, E., \& Ansary, H. (2005). The discourse structure of and sociopolitical strictures on TV commercials. Asian ESP Journal, 1(2), 94-107.

IA2. Fahim, M., \& Abednia, A. (2010). Investigating conflict between the critical nature of transformative language teacher development and student teachers' traditional background. Iranian EFL Journal, 6(2), 50-74.

IA3. Fahim, M., \& Bijani, H. (2011). The effects of rater training on raters' severity and bias in second language writing assessment. Iranian Journal of Language Testing, 1(1), 1-16.

IA4. Fatemi, M., \& Nabizadeh, J. (2012). The effect of Learning Strategies on the Speaking ability of Iranian TEFL sophomores. Iranian EFL Journal, 8(2), 9-26.

IA5. Motallebzadeh, Kh. (2009). Strategy-based instruction: A focus on Improvement of IELTS Speaking. Iranian EFL Journal, 2009(5), 93-114.

IA6. Pishghadam, R., \& Ghahari, Sh. (2011). The impact of glossing on incidental vocabulary learning: A comparative study. Iranian EFL Journal, 7(6), 8-29.

IA7. Pishghadam, R., \& Shayesteh, Sh. (2012). Conceptions of assessment among Iranian EFL Teachers. Iranian EFL Journal, 8(3), 9-23.

IA8. Ramzjoo, S. A., \& Raissi, R. (2010). Evaluation of SAMT ESP textbooks for the students of medical sciences. Asian ESP Journal, 6(2), 108-150.

IA9. Sabouri, A. (2009). Freire's bottom-up bridges student-centeredness: A rebuttal to Seyyed Abdolhamid Mirhosseini. The Asian ESP Journal, 5(1), 97-106.

IA10. Zarei, Gh. (2011). Functional analysis of Iranian learners' L2: Complimenting in written Discourse. International Journal of Language Studies (IJLS), 5(2), 109-122.

\section{Copyrights}

Copyright for this article is retained by the author(s), with first publication rights granted to the journal.

This is an open-access article distributed under the terms and conditions of the Creative Commons Attribution license (http://creativecommons.org/licenses/by/3.0/). 